\title{
THE DYNAMICS OF INNOVATION AND INVESTMENT, with application to Australia 1984 - 1998
}

\author{
Jerry Courvisanos
}

\author{
School of Economics, \\ University of Tasmania, Launceston \\ P.O. Box 1214, Launceston, \\ Tasmania 7250, Australia \\ Tel: +61 363243272 \\ Fax: +61363243369 \\ e-mail: Jerry.Courvisanos@utas.edu.au \\ Visiting Scholar \\ 1 July 1999 - 31 January 2000 \\ MERIT \\ University of Maastricht
}

January 2000 


\begin{abstract}
Ever since the start of the Industrial Revolution in Britain in the 1760s, innovation and investment have been crucial elements in economic explanations of the dynamics of capitalism. Classical economics recognises that innovation embodied in the form of new machines through fixed capital investment is the essential process for realising economic development. This study sets up a theoretical linkage between innovation and investment in historical time, without reference to any static equilibrium model. In this way, the relationship between instability of cycles and trend growth can be clearly identified.

A theoretical framework and specific model of innovation and investment are developed. This is followed by an empirical investigation in support of this analysis to show plausibility in the important linkages between innovation and investment that have been missed when examined through static analysis of these relations. The statistical analysis is based on recent Australian industry sector data (1984-98) on R\&D and capital expenditure in panel data form and in evolutionary industry life-cycle form. Conclusions from this work indicate the need to re-examine the way strategies are formed and developed in both the private and public sectors for more effective appropriation of innovation into the investment planning process.
\end{abstract}

Keywords: R\&D expenditure, industry life-cycles, Kaleckian investment, evolutionary innovation processes.

\title{
Acknowledgements
}

This research report has been produced while Visiting Scholar at MERIT, July 1999-January 2000. I acknowledge the financial support and teaching relief provided to me by the Faculty of Commerce and Law, University of Tasmania. Thanks go to all the MERIT staff for academic and physical support, especially when I failed to get on top of the Dutch systems. In particular, I wish to acknowledge the immense statistical and econometric support by Bart Verspagen (Eindhoven University of Technology and MERIT). All the tedious compiling, collating, concordance, and statistical testing were completed by my research assistant, Ameeta Jain who has an extremely quick appreciation of numbers. The employment of Ms. Jain was possible due to two Small Australian Research Council (ARC) grants, 1997-98 and 1998-99. Harry Bloch (Curtin University) is the intellectual support that enabled the ARC grant to reach this report stage. Thanks also to Paul Blacklow and Ted McDonald (University of Tasmania) for statistical help at various stages in the research. All interpretations and errors remain mine alone. 
...Kalecki's analysis provides for an endogenous rate of growth, albeit one which rests on the stimulating effect of innovation on investment. (Sawyer, 1996, p. 107)

\section{The Issue - Dynamics of innovation and investment}

Ever since the start of the Industrial Revolution in Britain in the 1760s, innovation and investment have been crucial elements in economic explanations of the dynamics of capitalism. Classical economics recognises that innovation embodied in the form of new machines through fixed capital investment is the essential process for realising economic development. This study sets up a theoretical linkage between innovation and investment in historical time, without reference to any static equilibrium model. In this way, the relationship between instability of cycles and trend growth can be clearly identified. Recent Australian industry sector data is used in panel data form and in evolutionary industry life-cycle form to identify important linkages between these two crucial elements that have been missed when examined through static analysis. Conclusions from this work indicate the need to re-examine the way strategies are formed and developed in both the private and public sectors for more effective appropriation of innovation into the investment planning process.

Technological innovative behaviour is based on the crucial input of research and development $(R \& D)$ expenditure. ${ }^{1}$ At the technological scientific level R\&D induces new technology systems and process innovation, while at the applied and experimental level $\mathrm{R} \& \mathrm{D}$ is used to adapt such new systems and processes to a wide range of product innovations. The more minor are the cost and product improvements that are associated with R\&D expenditure, the more mechanical the innovation process tends to be. Australian R\&D bifurcates into two quite distinct roles. There is the high public R\&D into basic research, which results in strong science-based output and is annexed quickly overseas. In contrast, the private sector spends most of its $R \& D$ on applied and experimental activities that involve the diffusion of overseas innovations into specific Australian-based product ranges.

In this study, $R \& D$ expenditure is the input variable into innovative behaviour that is under investigation. ${ }^{2}$ Innovation then in turn is appropriated as an artefact in the economy through the investment process. Expenditure of fixed capital plant and equipment is the measure of investment, and it represents spending on capital accumulation that creates the means of production (MOP) of all processes and products that enable the capitalist system to sell commodities in the marketplace. The dynamic roles of innovation and investment are examined through private expenditures on R\&D and MOP and then applied to specific industry sectors for Australia in the period since private $R \& D$ expenditures have been measured, that is, from 1984 to the latest available data in 1998.

\footnotetext{
${ }^{1}$ This study ignores non-technological innovation, based on organisational and labour practices and on new marketing angles that do not involve R\&D expenditure. Such innovative behaviour requires only a minor level of capital expenditure, and as such does not form a significant link between innovation and investment.

${ }^{2}$ Innovation behaviour is broadly knowledge-based and relates to many social and technological capabilities of an economy (see Woolgar, 1998). R\&D is one identifiable important foundation into this innovation process (see Freeman, 1995; Jankowski, 1998).
} 
The next section outlines the theoretical and empirical literature on innovation and investment, followed by exposition of the Kaleckian framework of analysis used in this study to link the two elements together. The dual structural method of employing the Australian statistics (evolutionary and panel data) and the statistical results from this dual approach are set out, followed by a pattern-matching explanation of the statistical results. A section follows that notes the technical details and limitations of the statistical results. Finally, a summary is presented indicating the policy implications of this analysis and future research required both at the statistical and policy levels.

\section{The Literature - Overview of theory and empirical evidence}

As the research field of economics deepened over more than two centuries since the Industrial Revolution, the linkage between innovation and investment developed by early classical writers has become more tenuous. Research in innovation and investment has tended to be uncoupled, with linkage between the two becoming sporadic. Only economists examining the economy as a vast interconnected "open systems" canvas continued to maintain this link; notably in respect to the heritage of this study we can identify Karl Marx, Rosa Luxemburg, Michał Kalecki and Joseph Schumpeter.

Innovation research has taken two roads. One is the road to broad-based evolutionary change in the long-term structure of capitalism, while the other is the road to narrowbased entrepreneurship studies at the firm level. Attempts to incorporate investment into the theoretical analysis of innovation have been limited (Stoneman, 1983, p. 202). Recent books that review the innovation literature continue to reinforce this theoretical limitation by having no analysis of innovation with investment (Dodgson and Rothwell, 1994; Freeman and Soete, 1997). Two major exceptions to this are Salter (1960) from the neoclassical perspective, and Freeman and Perez (1988) from the evolutionary perspective. Both innovation studies set up economic "snapshots" which provide case study patterns to show the plausibility of the theoretical relations they derive with respect to investment.

Salter examines technical change and its implications for MOP increments at the margin in different industry sectors. In an exceptionally insightful manner, Salter recognises the gap between available innovation and its application via investment. He uses market signals to indicate possible postponements in the use of introduction of more innovative MOP and consequent delays in scrapping old MOP, thus the capital stock becomes "fossilised" (Salter, 1960, p. 154). This exposes technical change to different rates of productivity between industries.

Freeman and Perez (1988) take a dynamic structural adjustment view of the economy in respect to innovation and note the mismatch of current investment to new available technology. Rather than market signals, this study notes the variations in the climate of confidence related to the type of innovation and the life-cycle of the industries which account for this mismatch, leading to intensified investment instability. The study concludes that:

The present wave of technical change sweeping through the world economy is likely to exacerbate the problems of instability in investment, 
and of structural change at the national and international level and the associated disequilibria in the international economy. (p. 63)

Investment research has also taken two roads. At the aggregate level, investment analysis in its capital accumulation form occupies a central role in effective demand of income determination and its impact on business cycles and trend growth. At the firm level, an analysis of investment decision-making relates to the economic rational determination of quantity of investment under various notions of uncertainty. In both forms, innovation (or technical progress, as it is more generally referred to in the investment literature) is characterised as a deuxs exs machina that adds an exogenous alteration to the investment configuration, without explaining the link between innovation and investment. The general justification for this is that "...the issues are quite complex and difficult to model." (Lavoie, 1992, p. 316)

From the neoclassical perspective, investment research generally ignores the role of technological innovation except as some exogenous force and only on a single firm basis when the role of entrepreneurship is brought into play. The central neoclassical literature on investment behaviour is based on the seminal work of Dixit and Pindyck (1994) where uncertainty is handled as calculable (or probabilistic) uncertainty, and capital stock is homogenous that implies no role for innovation. At the aggregate level, the endogeneity of technical change in the new growth models has still left the linkage highly tenuous. A recent review of this literature in relation to innovation concludes that:

Although such [permanent] innovations are important sources of fluctuations in macroeconomic data, they [new growth models] are unable to explain large proportions of fluctuations in observed economic data... Overall, the results reflect the inadequacy of one-factor neoclassical stochastic growth models in describing the dynamic behaviour of (real) macroeconomic variables, and suggest the need for alternative models of economic growth. (Hossain and Chung, 1999, p. 1081)

Alternative investment models with innovation are available. The classic proposition comes from Schumpeter (1939) where the investment function responds to waves of optimism and pessimism that create clusters of innovation and thus, "bunching" of investment. This leads to susceptibility for unstable investment cycles and the development of a trigger mechanism to initiate fundamentally new innovation systems with long wave implications. Kalecki (1962) reinforces the cycle-trend effect that innovation has on the investment function. ${ }^{3}$ The intensity of innovation affects both the amplitude of investment cycles and also shifts the trend path of investment growth, by flows of vicious and virtuous circles. Virtuous circle effect occurs as innovation intensity rises, increasing the amplitude of the upper turning point of the investment cycle and shifting the trend path upwards. ${ }^{4}$ Vicious circle effect increases the amplitude of the lower turning point and shifting the trend downwards. Steindl

\footnotetext{
${ }^{3}$ Kalecki (1991, p. 455) endorses the Schumpeterian view when he states that “...capitalists investing 'today' think to have an advantage over those having invested 'yesterday' because of technical novelties that have reached them." Note, Kalecki often uses the word "invention" instead of "innovation" in many of his discussions of technical progress. See Courvisanos (1996, p. 107) for resolution of this confusion.

${ }^{4}$ Empirical evidence by Toivanen et al. (1999) support the notion of this virtuous circle effect.
} 
(1979, p. 7) formalises this by considering the pace of innovation as a shift parameter of the Kaleckian investment function. Mensch (1979) provides an extensive economic history of the cluster innovation effect and its sequencing to investment.

The cause of clustering of innovation and subsequent bunching of investment ("clust-bun") is in debate (see Freeman, 1994, pp. 86-9). The common Kaleckian feature of expanded reproduction appears in this debate that has not been recognised by the protagonists in this debate. The prerequisite for clustering is deep depressions or breakthroughs in technology, both reflect reactions by private sector (in the former case) and public sector (in the latter case) to deep problems in the downswing of the previous business cycle. Then, the bunching requires effective demand stimulus through widespread diffusion of the cluster effect that can only be done through the availability of a surplus for investment (private profits and public deficit spending). Roadblocks to this "clust-bun" effect reside in the institutional frameworks of nations; particular the ones with still dominant mature industries with older technologies (Freeman and Perez, 1988, pp. 58-65). Increased uncertainty arising from large investment in the new technology systems also adds a roadblock through increased macroeconomic volatility, which Toivanen et al. (1999) empirically identify as slowing down the diffusion process.

The causality sequencing of innovation and investment is reversed by Kaldor (1961) and Schmookler (1966), with the rate of investment determining the rate of innovation. Kalecki also recognises this sequence, despite having identified the innovation-driven process (see especially footnote \#3 above). Kalecki places this investment-driven process clearly into an appropriate context by viewing this innovation process as “...part and parcel of 'ordinary' investment" (Kalecki, 1954, p. 158), or endogenous innovation. Geroski and Walters (1995, p. 926) empirical investigation supports endogenous innovation, concluding that demand matters, "...although it is evident that it plays only a relatively modest role in stimulating innovative activity". In a statistical note to this study, Collins and Yao (1998) argue that the data does not support this conclusion. Further, Geroski and Walters (1995, p. 925) themselves signal in a footnote (\#17) the possibility that "...more basic or fundamental [exogenous] innovations have different cyclical patterns from the less substantive [endogenous] innovations, and this may explain these differences in results."5

Instead of unidirectional causality, the discussion above clearly leads to a circular flow where one innovation process feeds into the other. Kaldor (1966) introduces the principle of cumulative causation, which is the "self-reinforcing dynamics" in the circular process of investment demand leading to innovation which then stimulates further investment. The distinction between exogenous and endogenous innovation specifies how innovation enters this cumulative causation process. In this context, Gomulka (1990, pp. 45-7) sees R\&D expenditure as central to the endogenous innovation process, with large firms with strong profit results having the ability to activate large $R \& D$ spending. Patents seem to reflect more the clustering of innovations (Geroski and Walters, 1995, p. 924).

\footnotetext{
${ }^{5}$ See Courvisanos (1996, pp. 44-50) for more on the distinction between endogenous and exogenous innovation from Kalecki's use of both these innovation processes.
} 
Concluding this literature review on the broad perspective, is a study that attempts to provide ergodic closure to the Kalecki trend and cycle theory. The study argues that Kalecki's central role of innovations in preventing the trend rate of unemployment from increasing is unsupportable, as "...the balanced growth rate which Kalecki took to be stable is, in fact, unstable, rendering it unsuitable to serve as the trend growth rate." (Gomulka et al., 1990, p. 535) Lavoie (1994, pp. 297-327) examines Kalecki's innovation and investment analysis at the theoretical level and rejects the ergodic closure assumption in Gomulka et al. which ties his theory to the neoclassical mainstream. Kalecki clearly assumes that the rate of capacity utilisation may diverge from its full-capacity rate even in the long run and the "...reserve army of the unemployed are typical features of capitalism at least throughout a considerable part of the cycle." (Kalecki, 1971, p. 137) This asserts instability, as the dynamic non-ergodic business cycle has innovation creating conditions that move the trend growth away from any analytical "stability". At the practical level, Kalecki's time unit of analysis of one year is sufficient to avoid any "...unsuitable solutions of the equation." (Steindl, 1991) The conclusions here are important, since the next section uses a non-ergodic dynamic Kaleckian model of cycles and trend to link innovation and investment in order to analyse the empirical data subsequently presented.

\section{The Model - Kaleckian macroenvironment and industry analysis}

A three phase model-building structure is developed in this section. First, a description of the Kaleckian framework of analysis within which the model is operating is set out. This clearly sets up the dynamic mechanisms and absolves the ensuing model from any need to find stability conditions or any other neoclassical presupposition. Second, a flow-chart is provided to show how the dynamics operate over historical time to furnish both cycles and trend with innovation as crucial to the investment process. Third, establish a series of equations and a grid matrix specifically applied to tell a plausible story with the statistical data available in Section 4 that follows.

\subsection{Descriptive Kaleckian framework of analysis}

Using Kalecki's extended reproduction model, three observable variables are central to Kaleckian investment decision-making firms. These are profits, increasing risk (extending the gearing or leverage ratio) and excess capacity. Within an institutional framework of monopoly capitalism, a susceptibility cycle model is developed by Courvisanos (1996) which measures the tensions that are built up when investment decisions are being made, with the three variables above acting as the barometers of this tension. During an investment boom, these tensions grow to such an extent that investment is highly susceptible to a collapse. In a historical context, such high susceptibility can be identified with falling profit rates, increased finance costs and gearing ratios, and falling utilisation rates. This build up of tension is based on the implementation of a long run firm investment strategy. When high susceptibility is reached, any minor factor (endogenous to the susceptibility cycle or exogenous) can add another small amount of tension that will be enough to suspend or cancel investment orders, sending the investment (activity) cycle down as a result. 
At the upper turning point of the susceptibility cycle, all firms experience high susceptibility and thus fragility of the situation induces a reversal in investment orders. The investment downturn that follows is timed tightly around the pressures to contract investment which affect all firms to a varying degree, but at the same time. The timing and amplitude of the lower turning point is much more problematical than the upper turning point. Pressures to contract investment orders come from too high susceptibility across all firms. Pressures to expand investment orders come when susceptibility is low, and it depends on the more problematical issue of when a firm (or industry) wants finally to take the plunge. Tightly owned companies with less risk aversion tend to lead investment orders out of the doldrums, while the State tends to assist firms during this period by reducing costs of production through direct (e.g. subsidies) and indirect (e.g. unemployment benefits) deficit spending. These two factors strongly determine the timing and nature of the upturn.

Based on Kalecki's view of innovation, endogenous innovation is of secondary importance from the scientific standpoint, coming as it does from:

(i) slight improvements or adaptations on previous capital equipment;

(ii) some improvement in quality or design or new packaging of old products so that they look "new" (e.g. fins on an old style car model);

(iii) some new "vein" or extension of previous raw material sources.

This innovation is most common and involves new investment spending as a matter of course when business is ongoing. In relation to the susceptibility cycle, such innovation is called endogenous because it is the cycle itself that induces the innovation and with it, higher levels of investment orders. ${ }^{6}$

The firm's R\&D expenditure is a form of intangible investment to be incorporated in the long-term business investment plan. This enables the firm to hold a stock of innovations that are ready to be applied when susceptibility is relatively low. In this way endogenous innovation can be "...generated and directed by a process of investment" (Steindl, 1976, p. 133). When a firm decides to increase investment at relatively low susceptibility under competitive pressures and higher costs of postponement, the R\&D investment in the past makes these innovations ready to implement. ${ }^{7} \mathrm{R} \& \mathrm{D}$ investment effectively increases the strategic capacity of the firm, enabling it to increase MOP that are innovative. R\&D expenditure may be constant throughout the investment cycle, or may vary under the same susceptibility pressures as MOP commitments. Which of the two it is depends on how important R\&D is for the firm and industry. In an industry where innovation is a regular competitive strategy, $R \& D$ expenditure would be large and would vary under the same susceptibility pressures as capital expenditure. In an industry where innovation is only occasionally implemented, $R \& D$ expenditure would be small and constant over the investment cycle.

At high susceptibility firms are under pressure to postpone investment orders, and with it shelving of endogenous innovations and possible reduction of $R \& D$ expenditures. This

\footnotetext{
${ }^{6}$ Steindl (1976, p. 133) describes this endogenous innovation very neatly: "Technological innovations accompany the process of investment like a shadow, they do not act on it as a propelling force."

${ }^{7}$ The firm can also buy out smaller uncompetitive firms during the contractionary stage of the investment cycle, taking advantage of innovations developed by failed firms.
} 
alleviates pressure of growing susceptibility, by concentrating on profit returns from old MOP which has a proven track record from its production, rather than the higher but more unpredictable returns from new MOP. ${ }^{8}$ Only small increases in capacity investment to protect existing MOP emerge at high levels of susceptibility. In the cyclical context, endogenous innovation postponement is induced from high susceptibility and it then adds pressure for the slow down and eventual contraction of investment orders. In the trend growth context, any long postponements of new innovative capital investment would produce a mismatch of current investment to new available technology in the economy, creating a roadblock to the "clust-bun" effect.

At low susceptibility firms introduce endogenous innovations, both in the form of process and product innovation, under the pressure of competition. Given that the technostructure needs to implement the long-term investment strategy with innovation incorporated therein. ${ }^{9}$ Then this need creates increasing competitive pressure during the contraction of the susceptibility cycle when investment orders are declining and little new investment is going on. The costs of postponing a long term investment strategy increases over time with the knowledge that other large firms in the industry (or ready to come into the industry) have the technology also to increase their market share and growth. These pressures, along with pressures for State-based stimulus, lead to some increase in investment embodied with endogenous innovation.

The creation endogenously of innovations out of low susceptibility makes some MOP obsolete and thus not part of excess capacity calculation. Also, oligopoly firms (and industries) lobby for the assistance of governments in reducing social costs of production (through subsidies, tax concessions or protection) when these firms attempt to expand their market by innovations in order to utilise new, and decommission old, idle productive capacity (O'Connor, 1973, p. 27). Such innovation and under-writing of the related risks reduce the rate of increase in susceptibility and encourages an investment recovery. However, these actions by firms and governments are not guaranteed to occur at any particular time or with any particular force. The institutional framework of a country (and region) will have a lot to do with the strength and timing of the upturn in investment orders.

R\&D amounts in aggregate to a large body of investigation going on continuously (at different rates of intensity). This large $R \& D$ spending and related innovation effects are bound to lead to some major new "discovery" or "invention" which is related to the total aggregate $R \& D$, rather than any particular one $R \& D$ project. This discovery is linked to possible small developments in various laboratories and informal networks between firms and industries, eventually coming to fruition in some way divorced of any specific competitive behaviour. New technological paradigms come out of such aggregate developments and are the basis of structural change to a new long wave of boom and prosperity (Freeman and Perez, 1988, pp. 47-58). Changes in technological systems and paradigms arise only after all the minor improvements (endogenous innovation) are

\footnotetext{
${ }^{8}$ See Toivanen et al. (1999) for empirical support.

${ }^{9}$ See Galbraith (1974) on the role of technostructure in planning investment strategies and specific technologies for the ongoing survival and growth of the large corporation. For a recent re-interpretation of the technostructure from a Post-Keynesian perspective, see Dunn (2000).
} 
squeezed out of the old systems and paradigms by "monopoly capital" entrepreneurs who want to protect existing MOP and delay the new paradigm taking over. There is also "log jam" in endogenous innovations based on the new paradigm which compounds the latter's slow initial adoption. This occurs when established powerful entrepreneurs, with much old MOP, cannot justify the entire shake-up of industries, since not enough interrelated clusters have been formed. ${ }^{10}$

Technological paradigm shift leads to exogenous innovation input affecting the susceptibility cycle. Introduction of a new paradigm produces a large exogenous boost to industry investment at low susceptibility points. This investment boom relates to paradigm changes in large important industry sectors that adopt new technology systems (e.g. petrochemical innovations), or in the whole economy (e.g. steam engine innovations). Either way, the investment boom is strong and resilient over a series of future cycles in susceptibility.

Exogenous innovation occurs in an industry generally at the low susceptibility point, where competitive pressure exists on entrepreneurs to introduce it. When investment activity is high and susceptibility is high, entrepreneurs are not receptive to major new developments, but rather continue squeezing profits from the old paradigm, given the already large commitments made to this old paradigm during the rise of investment from the trough. As susceptibility is falling with investment order downturn, the financial constraints of high gearing in the industry are eased as debts are paid off or receivers are appointed. At low susceptibility the industry is financially restructured and becomes conducive to new investment orders. However, at this point it is not clear if or when the lower turning point of investment orders will be based on the decreasing opportunities from the old paradigm (providing only a modest upturn) or on the uncertainty of the new paradigm. Breakdown of an old technological paradigm occurs in readapting this old paradigm through minor innovations. Uncertainty of future profits reduces investment orders and susceptibility further. At this point even replacement investment is postponed, sending the susceptibility cycle even lower.

As the institutional framework slowly adapts to the new technological system, entrepreneurs' reactions against uncertainty of profits come from competitive pressures and growing inefficiencies of old MOP. This induces adaptation (by industries) and imitation (within industries) to technological trajectories that are totally new, establishing at very low susceptibility, the new investment upturn. It is creating a new investment boom and at the same time "...re-establishing the conditions for a new phase of steady development." (Vercelli, 1989, p. 135) A paradigm shift occurs when the new adapted technological systems pervade the whole economy. Many from the evolutionary school identify such a shift with the beginning a new long wave in the economy's development (see Kleinknecht, 1987).

Analysis in this section allows linking together the two types of innovations described by Baran and Sweezy (1966), namely "normal" (or endogenous) and "epoch-making" (or

\footnotetext{
${ }^{10}$ For example, separate innovations in different aspects of a lightweight solar car have been developed, but a strong enough cluster has not been formed to push the steel petrol engine into the museum.
} 
exogenous). A period of secular decline in economic development can now be associated with the limitations of scale production in oligopolistic competition, as the old technology systems are running out of possible new adaptations. Diffusion of the old systems through endogenous innovation slows down and imitators become considerably fewer. The large powerful corporations attempt to protect existing capital values and ignore the new technological systems being developed on the fringe of the corporate world. This tends to exacerbate the mismatch between new technologies and powerful institutional framework based around monopoly capital. It was Steindl, back in 1952, who recognised this secular decline as the incentive to reduce surplus capacity and invest in established monopoly capital sectors. In his 1976 introduction to the 1952 book reprint, Steindl stated that he was "...ready to admit a possibility which I denied in my book: that it might be the result of exhaustion of a long technological wave" (1976, p. xv). In this way, the conclusions of the Kaleckian and evolutionary traditions can be integrated.

\subsection{Flow-chart macroenvironment and instability}

Figure 1 summarises in aggregate terms the dynamics of cycles and trend described above. The figure will be used in this section to show how these dynamics set the macroenvironment of virtuous and vicious circular flows within which the firms and their entrepreneurial agents conduct innovation and investment decisions.

\section{Figure 1: Circular flow of innovation and investment}

National Innovation System

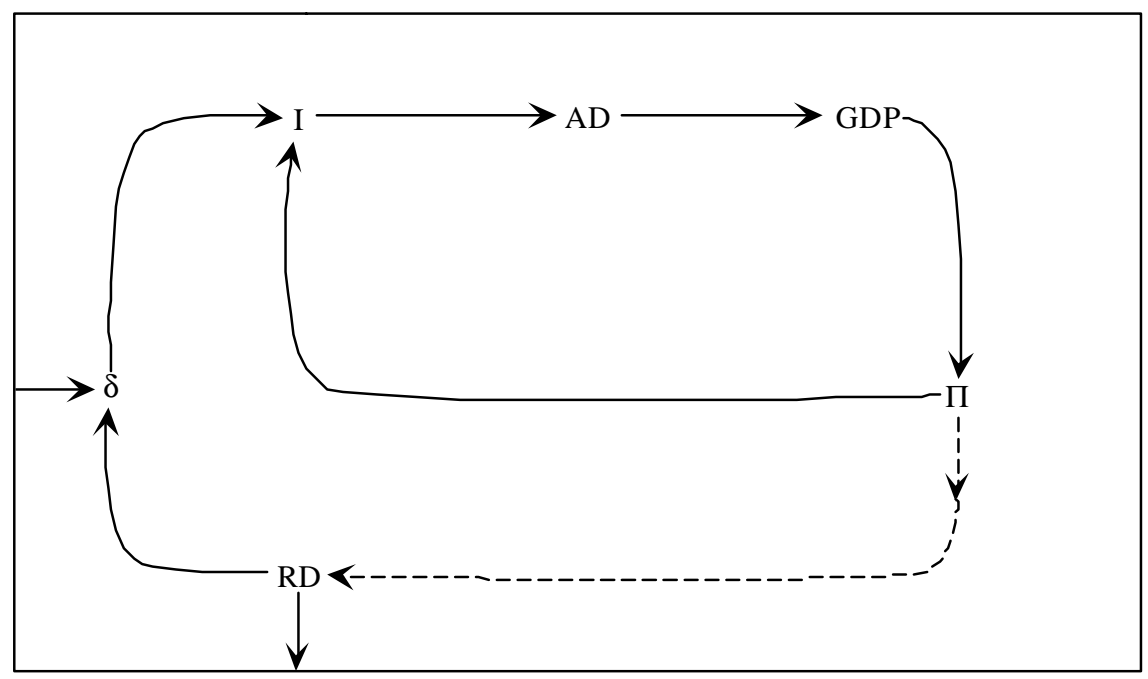

The outside perimeter of Figure 1 is the National Innovation System (NIS) which carries the institutional framework within which endogenous and exogenous innovation occurs, and investment cycles operate. Freeman (1995) provides the historical context for such NIS to exist, and explains how such systems determine the way new and old technological paradigms interact within the national boundaries. This perimeter framework can also be adopted at international regional levels (e.g. EU, NAFTA, ASEAN) and at sub-national regional levels, only the specifics of each perimeter need to be established. The role of the 
state is not specifically identified in Figure 1, with its influence remaining in the NIS perimeter, while the circular flow itself has no government sector and no impact through public expenditures and revenues (taxes, etc.).

Figure 1 is a circular flow through historical time. The explanation of the circular flow diagram within the NIS can begin at any point without any loss of explanatory power. Following Ricottilli (1996), the explanation begins with the innovation decision-making process and it is specified as equation 1 :

$$
\delta=\mathrm{f}_{1}(\mathrm{RD}, \mathrm{L})
$$

where $\delta$ is change in technology (or simply innovation), and it is dependent on the extent of $\mathrm{R} \& \mathrm{D}$ expenditure input (RD) and the current cognitive learning and institutional knowledge capabilities (L) measured in efficiency units. The $\mathrm{L}$ term is determined by the given state of the NIS, including networks of social relations ${ }^{11}$ and technological capabilities imported from overseas through licensing, joint ventures and foreign direct investment. In Figure 1, two arrows pointing to the $\delta$ variable represent equation 1 .

Equation 2 states that: $\quad I=f_{2}(\Pi, \delta)$

where I is investment (or the rate of change of MOP), and it is dependent on the profit level $(\Pi)$ and innovation $(\delta)$. Profit levels represent the extent that retained earnings are used for funding investment, while $\delta$ represents the endogenous flow of innovation incorporated into investment as discussed in Sub-section 3.1. These two variables form the crucial decisionmaking elements that relate to the level of susceptibility in the investment process. The $\Pi$ level in a Kaleckian framework also indicates the ability of firms to obtain external funds through the principle of increasing risk (Kalecki, 1937), which explicitly identifies stronger profit levels as the increasing ability of firms to attract riskier external sources of funds. Higher $\Pi$ overall gives entrepreneurs stronger positive expectations for implementing the investment decisions on the basis of equation 2 .

A more sophisticated investment model than equation 2 would be represented by profits as the essential extended reproduction variable, but also including the change in profits (expectations), increasing risk (gearing ratio) and capacity utilisation as explained in Subsection 3.1. ${ }^{12}$ This paper concentrates on the innovation-profit-investment linkage, with gearing ratio and capacity utilisation rates not systematically analysed.

In Figure 1, the circular flow from investment (I) follows a standard Keynesian macroeconomic route, as I feeds into aggregate demand (AD) as its most volatile component even though it generally accounts for around 20 per cent of total AD. Then, changes in AD directly affect the income determination level (or GDP). The changes in GDP directly impact on the distribution of profits $(\Pi)$ which consists of a given stable level of distributed earnings, while the rest is the variable retained earnings (RE) for investment (see Asimakopulos, 1975). RE generally accounts for around 75 per cent of total business fixed

\footnotetext{
${ }^{11}$ See Woolgar (1998) on the need for "...a process of changing networks of social relations" (p. 451) in the NIS.

${ }^{12}$ See Courvisanos (1996, pp. 161-2) for the exposition of this more sophisticated investment function.
} 
investment in capitalist economies. It is this RE element which represents the direct profit flow of funds back into investment (I). ${ }^{13}$

In his review of the innovation literature, Gomulka (1990, pp. 45-7) identifies the important influence of profitability on the level of R\&D spending in the aggregate, despite larger firms tending to spend a lesser proportion of profits on $R \& D$ than smaller firms. In more general terms, Kalecki (1962) supports this same position but notes the long and complex time-lag involved for profits to influence "the stream of inventions". Thus, the Figure 1 flow from $\Pi$ to RD is more variable than the $\Pi-I$ flow and importantly, also occurs over a longer time horizon. This is represented by a dotted line, indicating that this flow is not in the same time dimension as all the other flows. All unbroken line flows tend to be more direct and quicker in their impact on the variables they flow on to. For the empirical research in the next section that is based on a relatively short timeframe, $\mathrm{RD}$ is considered as exogenous.

To close the circular flow, RD has two flow impacts. One is the already identified monetary flow into innovations via equation 1 . The other is the RD input flow, in terms of aggregate expenditure from all firms, directly into the NIS. ${ }^{14}$ Larger RD has a positive impact on the knowledge and learning capabilities of any given NIS. The input is direct, but the impact on NIS is cumulative over a long historical process. Within the dominant technological paradigm, the effect is for exogenous innovation to flow through the $\mathrm{L}$ term back into the circular flow and to the $\delta$ variable. At the same time, a "constellation" of technical and economic factors mounts up towards a structural break where a new paradigm emerges, altering radically the given NIS. When the radical break occurs, exogenous innovation becomes the crucial factor through the $\mathrm{L}$ term in the paradigm shift and that leads directly to a strong expansion of the investment cycle (as discussed in Sub-section 3.1).

Dynamics of this circular flow can be exhibited by the explication of the virtuous and vicious circles defined in Section 2. The virtuous circle can be seen in aggregate when increase in RD leads to a rise in $\delta$, which encourages expansion of I (Nickell and Nicoltsas, 1996). This has a direct positive impact on AD, GDP and consequently on $\Pi$, which then creates an accelerationist effect on I flowing through greater economic activity and the expansion phase of the investment cycle. An endogenous innovation-based reinforcement of this circle is the increased innovation intensity via the dotted flow-line from $\Pi$ to $R D$ adding another rise in $\delta$ to push the expansion phase further into a strong boom. This dynamic circle exhibits innovation intensity deriving from the growth industries of the endogenous innovation effects of a powerful exogenous technological paradigm. The virtuous circle has all the elements associated with the "Schumpeter Mark II" effect that Malerba and Orsengio (1993) identify, where increase in RD leads to "creative accumulation".

As investment orders build up there is an increase in susceptibility to an investment downturn through the normal route of growing excess capacity, rising gearing ratios and

\footnotetext{
${ }^{13}$ On the theoretical details of the "double-sided relation between profits and investments", see Asimakopulos (1977).

${ }^{14}$ See Jankowski (1998) for evidence on both roles of R\&D in the foundations of innovation even as structural changes alter its nature and activity, reflecting the shift to information technology R\&D and its input into the services sector.
} 
tensions when $\Pi$ is high, but the relative increases in $\Pi$ slow-down and even begin to decrease (see Courvisanos, 1996, p. 161). Given the constancy of the capacity and gearing variables this simplified model, Figure 1 can isolate a further susceptibility tension via the innovation link to the virtuous circle. As RD continues its endogenous innovation push, there is tension with the development a greater economic uncertainty in investment more "new" products and processes, as identified by Driver and Moreton (1992). This is the "Schumpeter Mark I" effect, where new innovations have the creative destruction of older "established" MOP value which has strong monopoly control. Depending on the NIS framework, this problematic tension to the virtuous circle will appear as a strong negative susceptibility force at different intensities of the endogenous innovation-based expansion phase in the investment cycle. ${ }^{15}$ Such negative susceptibility ensures that no expansion phase of the investment cycle can ever be permanent, as the level of fundamental uncertainty will continue to rise disproportionately to the acceleration of the virtuous circle effect.

The vicious circle appears in the contraction phase of the investment cycle, when the susceptibility tensions of the expansion phase have eventually created the upper turning point. In aggregate when there is a decrease in $\mathrm{RD}$, this leads to a decrease in $\delta$, which discourages I as well. This has a negative impact on AD, GDP and consequently on $\Pi$, which then creates a negative accelerationist effect on I flowing through lower economic activity and the contraction phase of the investment cycle. An endogenous innovation-based reinforcement of this circle is the decreased innovation intensity via the dotted flow-line from $\Pi$ to $\mathrm{RD}$ adding another fall in $\delta$ to push the contraction phase further into a strong recession. This vicious circle exhibits innovation intensity that is very weak, deriving from the mature industries of the long established endogenous innovation effects of a monopoly controlled "old" exogenous technological paradigm.

In the susceptibility cycle, investment contractions lead to a problematic downturn of indeterminate speed (slope of the contraction) and trough of indeterminate intensity and length (amplitude and periodicity). The susceptibility levels fall by the extent of the profit falls and the speed that balance sheets are restructured after serious gearing-based failures. The length of the trough depends on competitive pressures and higher costs of postponing endogenous innovation-based investment. The growing inefficiencies (both technical and market related) of old MOP weaken the strategic capacity of firms to the point that this established MOP capacity is decommissioned and investment begins to build up again with endogenous innovations. These pressures undermine the vicious circle effect, to the point that it shifts into a virtuous circle effect. These same pressures are greater under the influence of a new exogenous-based technological paradigm, whereas under the monopoly control of a mature technology paradigm there is less pressure with greater likelihood that the vicious circle will continue for a longer period.

\footnotetext{
${ }^{15}$ There is evidence that in the 1990s this innovation-based susceptibility has taken root much more quickly and strongly in Europe than in the USA and Australia. In the latter nations the information technologybased innovation expansion phase has been very strong compared to that of Europe (see Hollanders et al., 1999).
} 
Operation of the two circular flow effects above result in irregular investment cycles of variable volatility. These cycles have varying degree of fluctuation in terms of investment activity, and it is expressed as a variance (or standard variation) of the I variable. Although endogenous innovations have an influence on this instability via the amount of $\mathrm{I}$, it is the influence of exogenous innovations that distinguish clearly periods of low volatility (with established industries in monopoly control) and periods of much higher volatility, when a new technological paradigm is being implemented. Successful implementation of such new systems will provide strong expansion out of a deep recession, creating an impression of powerful stable growth in an ahistorical perspective. From the historical perspective, this is a very strong expansion phase of the investment cycle with growing susceptibility pressures for an eventual strong downturn. Less successful implementation of the new systems will result in many aborted efforts to rise out of the deep recession, with only limited success, but also with limited build-up of susceptibility pressures that provides only weak contractionary pressures. Combination of these two patterns on a global perspective have emerged in the 1990s (former being the South East Asia and USA, latter being Europe and Southern Asia) showing convergence within global regions, and divergence across different global regions (Hollanders et al., 1999).

\subsection{Equations and grid matrix for industry sector analysis}

Depending on the available data and the level of complexity introduced in the statistical research, different equations can be developed out of Sub-sections 3.1 and 3.2 above. An equation that examines the flows from $\mathrm{RD}$ and $\Pi$ to $\mathrm{I}$ within the circular flow diagram is specifically developed in this sub-section. The equation is then applied to a set of Australian statistical data in order to tell a plausible story at the industry sector level of the dynamics of innovation and investment. Equation 3 encapsulates the essence of the circular flow diagram with equations 1 and 2, in the form of a dynamic version of a Cobb-Douglas function, such that:

$$
\mathrm{I}=\mathrm{c} \Pi^{\alpha} \mathrm{RD}^{\beta}
$$

where $\Pi$ and RD are the two variables that influence I, given the short term constancy of the $\mathrm{L}$ term. The constant $\mathrm{c}$ has all other influences, notably the role of the state on investment. Note that Equation 3 specifies investment as a multiplicative function of profits and R\&D, so that raising one of these two "inputs" also increases the "efficiency" of the other.

Given the available time series data that has a large absolute range of numbers from very small to very large, it has been necessary to turn equation 3 into log form such that equation 4 reads:

$$
\ln I=\ln (\mathrm{c})+\alpha \ln (\Pi)+\beta \ln (\mathrm{RD})
$$

It is the form of equation 4 that investment will regressed in the data that follows. The $\Pi$ to RD link is longer-term and is left as statistically exogenous, while the link from I across 
to $\Pi$ is given by the aggregate demand effects of the rate of investment, which determine to a large extent capitalists' profits. ${ }^{16}$

From the perspective of industry life-cycles, the discussions above can be summarised in the grid matrix of Table 1. A grid matrix enables empirical patterns in qualitative terms to be identified, from which classifications can be constructed that assist in explaining the regression results in the equations that have been developed above. Table 1 differentiates the role of innovation in industries according to their life-cycles and type of RD. The Table then relates each of the industry life-cycle stages to their respective effects on investment decision-making in these industries, and impact on aggregate investment as industries cluster within these respective stages. This grid provides the basis for the evolutionary method used to analyse the statistical data of the industry sectors and their contributions to the innovation-investment process.

Table 1: Stages of industry development - innovation and investment

\begin{tabular}{|c|c|c|c|c|c|}
\hline $\begin{array}{c}\text { Life-cycle } \\
\text { Stage }\end{array}$ & $\begin{array}{l}\text { Type of } \\
\text { industry }\end{array}$ & $\begin{array}{c}\text { Type of } \\
\text { R\&D }\end{array}$ & $\begin{array}{c}\text { Role of } \\
\text { innovation }\end{array}$ & $\begin{array}{c}\text { Effect on } \\
\text { investment } \\
\text { decisions }\end{array}$ & $\begin{array}{c}\text { Impact on } \\
\text { aggregate } \\
\text { investment }\end{array}$ \\
\hline Infant & $\begin{array}{l}\text { Leading-edge } \\
\text { technologically } \\
\text { sophisticated }\end{array}$ & $\begin{array}{l}\text { High capital- } \\
\text { intensive. } \\
\text { Basic \& } \\
\text { applied }\end{array}$ & $\begin{array}{c}\text { Process } \\
\text { innovation } \\
\text { central }\end{array}$ & $\begin{array}{l}\text { Exogenous } \\
\text { stimulation for } \\
\text { investment } \\
\text { rise, strong } \\
\text { susceptibility }\end{array}$ & $\begin{array}{l}\text { Minimal, as } \\
\text { not enough } \\
\text { critical mass } \\
\text { for aggregate } \\
\text { effect }\end{array}$ \\
\hline Growth & $\begin{array}{c}\text { New } \\
\text { technology- } \\
\text { based mass } \\
\text { market }\end{array}$ & $\begin{array}{l}\text { Strong labour- } \\
\text { expanding. } \\
\text { Applied \& } \\
\text { experimental }\end{array}$ & $\begin{array}{c}\text { Product } \\
\text { innovation } \\
\text { central }\end{array}$ & $\begin{array}{l}\text { Stimulation to } \\
\text { increase } \\
\text { market share, } \\
\text { subdued } \\
\text { susceptibility }\end{array}$ & $\begin{array}{c}\text { Strong } \\
\text { expanding } \\
\text { cycles with } \\
\text { upward trend }\end{array}$ \\
\hline Mat & $\begin{array}{c}\text { Dominant } \\
\text { scale-intensive } \\
\& \text { information- } \\
\text { intensive } \\
\text { technologies }\end{array}$ & $\begin{array}{l}\text { Low or zero. } \\
\text { Labour-based } \\
\text { \& experimental }\end{array}$ & $\begin{array}{c}\text { Fears of } \\
\text { overcapacity; } \\
\text { technological } \\
\text { frugality }\end{array}$ & $\begin{array}{l}\text { Concentrate on } \\
\text { greater } \\
\text { utilisation, high } \\
\text { susceptibility }\end{array}$ & $\begin{array}{c}\text { Sustained } \\
\text { capital stock } \\
\text { levels \& weak } \\
\text { expansion } \\
\text { cycles }\end{array}$ \\
\hline Transition & $\begin{array}{l}\text { Old dominant } \\
\text { technology- } \\
\text { based, altering } \\
\text { to new } \\
\text { technology }\end{array}$ & $\begin{array}{l}\text { Refocus on } \\
\text { new capital- } \\
\text { based \& more } \\
\text { applied }\end{array}$ & $\begin{array}{l}\text { Major product } \\
\text { innovations; } \\
\text { alter processes } \\
\text { \& diversify }\end{array}$ & $\begin{array}{l}\text { Structural shift } \\
\text { in control, joint } \\
\text { ventures; leads } \\
\text { to severe } \\
\text { susceptibility }\end{array}$ & $\begin{array}{c}\text { Exacerbate } \\
\text { instability in } \\
\text { investment } \\
\text { cycles by } \\
\text { dominant firms }\end{array}$ \\
\hline
\end{tabular}

Source: Adapted from Courvisanos (1996, p. 201)

Based on empirical work, Scherer (1984, p. 4) has a graph showing RD leading I in industry sectors. Figure 2 applies the life-cycle stages in Table 1 to the Scherer graph. The length of stages will greatly vary across industries, and Figure 2 being schematic only should not be interpreted as if each stage is of equal length of time. This figure draws together RD and I in an evolutionary approach to provide the basic theoretical

\footnotetext{
${ }^{16}$ The Kaleckian I to $\Pi$ link ("capitalists get what they spend") has been confirmed by a series of empirical studies covering the U.S.A. (Asimakopulos, 1983), U.K. (Arestis et al., 1985-86) and Italy (Sylos Labini, 1967; and Del Monte, 1981).
} 
pattern as a template for pattern-matching examination of each industry sector's RD and I data. Figure 2 shows gross endogenous investment (new net investment plus replacement investment) take-off after industry has come out of the infant stage when relatively little investment is going on at the time when RD is essentially basic and the sophisticated end of applied RD.

In Part I of the growth stage the industry is rapidly evolving with much applied and experimental development RD leading to an increasing rate on essentially new investment. Part II of the growth stage has applied and experimental RD decreasing and new investment continuing to increase but at a decreasing rate. RD falls to virtually zero in the mature stage as only replacement investment keeps the level of gross investment constant. Human resources devoted to RD are the highest in this growth stage, with associated large labour-intensive RD activities.

In the final stage, industries have two alternative paths. One path is the transition stage (t) which meets the challenges of new technology systems through the industry reinventing itself with initially lower investment and then taking-off into new investment "on the back" of strong RD input. The other path is the decay stage (d) which leads to industry decline, with no RD and only replacement investment, which eventually creates such large excess capacity that even replacement investment collapses.

\section{Figure 2: Schematic representation of industry life-cyle R\&D and investment}

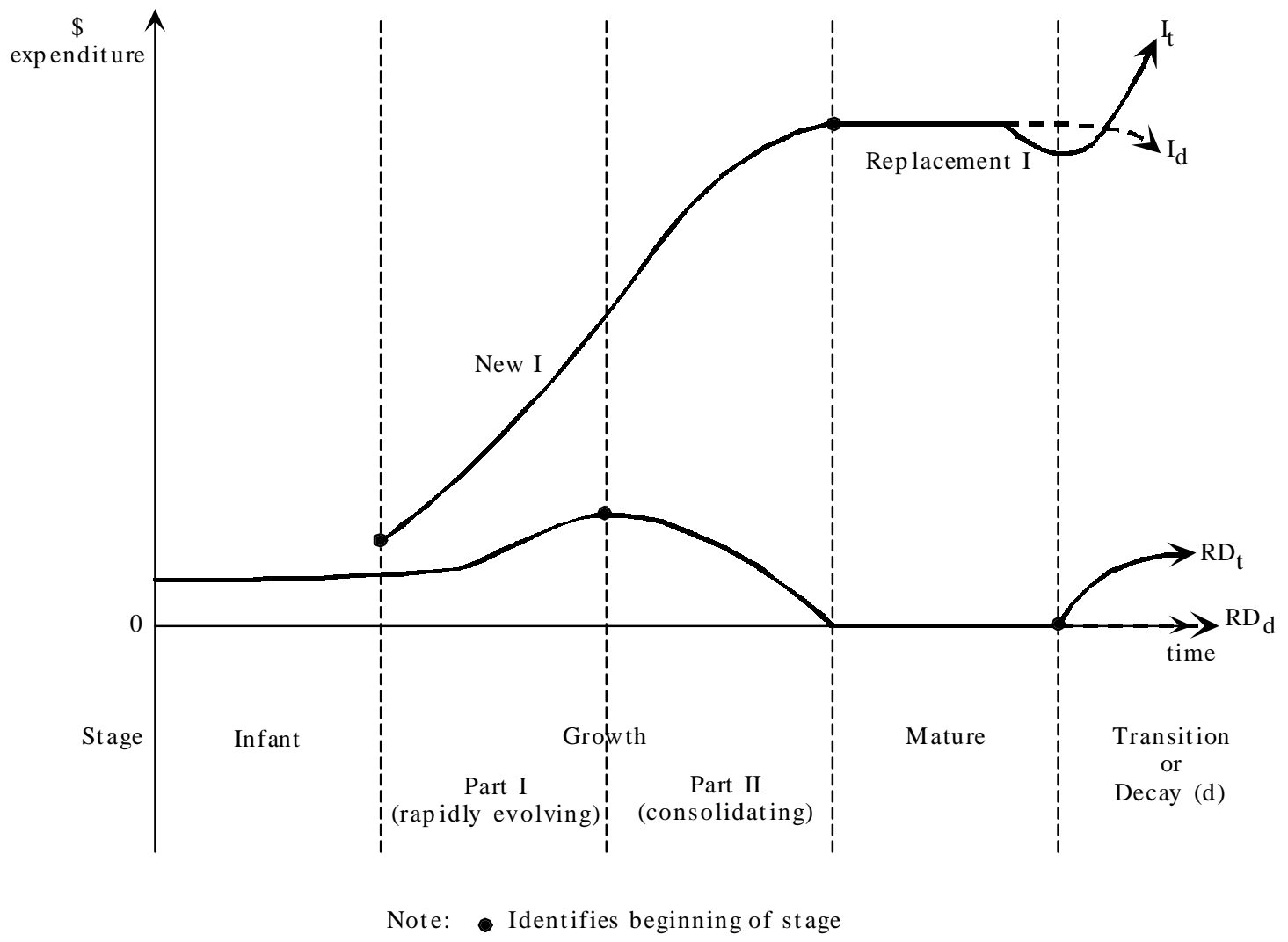




\section{The Australian Data - Structure and results}

Australian industry sector data from the Australian Bureau of Statistics (ABS) are collated annual in financial years (July-June) from when R\&D expenditure become available on a regular basis (1984-85) up till the latest available R\&D figures (1997-98). Figures for profits and investment for the same years have also been collated and set up in accord with the R\&D figures to obtain a complete data set that is then used in statistical and evolutionary grid analysis. To set the specific macroenvironment, Figure 3 shows levels of investment (I), GDP or Gross Domestic Product (as proxy for $\Pi$ ), and Australian patent applications in the USA (proxy for $\delta$ ) in index number terms with the base as 1950. The data extends from 1950 through to 1998.

Observation of the investment cycles in Figure 3 shows subdued cyclical activity with a modest upward trend through the "Golden Age" (1950-1974), when there was a regulated and but growing industrial structure. As the industrial structure became more deregulated and mature, susceptibility increased with fears of overcapacity, technological frugality and market uncertainty in the face of new (information technology) exogenous innovations that threatened a shift to a completely new industrial paradigm (see Freeman and Perez, 1988, pp. 52-3). The trend of the cycles has increased, as have the amplitudes of these cycles. This increased volatility and rising trend since the 1979-81 "resources boom" happen to coincide with when the R\&D published figures first appear and help to map the progress through structural change from the old dominant energy-based technological paradigm to the new dominant information-based paradigm.

The observed increased volatility of investment cycles in the 1980s and 1990s raises strong concern over the neoclassical interpretation of investment cycles that they are the outcome of normal lumpiness of investment projects and the competitive pressures towards efficient equilibrium. Lumpiness of investment in mature energy-based manufacturing industries magnifies susceptibility in cycle troughs under conditions of large excess capacity, as firms are hesitant to make large long-term future commitments. ${ }^{17}$ With the rise of information-based service industries, shorter time lags and quicker modification of investment orders result in relatively smaller "lumps", but with more demand-responsive capacity decisions. This results in more unstable investment cycles, having both very sharp investment expansions and then many small business failures and much "reinventing the wheel" by new entrants. ${ }^{18}$ Competitive pressures lead to greater variations in susceptibility as expanding industries continually move through technical and market uncertainty in the dynamics of disequilibrium.

Patents have a cyclical pattern in Figure 3 that closely resembles that of investment, but at a consistently lower growth trend. Indicative of the established nature of the energybased technology paradigm, the early post-war has a stable and even slightly declining

\footnotetext{
${ }^{17}$ In aggregate terms this lumpiness tends to be "washed out" by the spread of investment spending over many years and the bunching of investment by large firms in different industries of the immediate post-war. (Courvisanos, 1996, pp. 211-2)

${ }^{18}$ Early post-war evidence in the USA shows that "...there is a much wider fluctuation of capital investment among small than among large organisations" (Boatwright, 1954, pp. 109-10).
} 
level of patents. From the mid-1960s there is a marked rising trend in patents and an acceleration of this growth after the 1981-83 economic contraction, together with greater volatility. There seems to be a particularly strong late 1990s rise in patents, but the time period is too recent and too short to draw any conclusions yet from this. The pattern of patents provides á priori support for the innovation-investment link developed in theory above, and justifies examining this relationship through the $R \& D$ data available.

Figure 3: Australian time series - investment, patents and GDP 1950-98

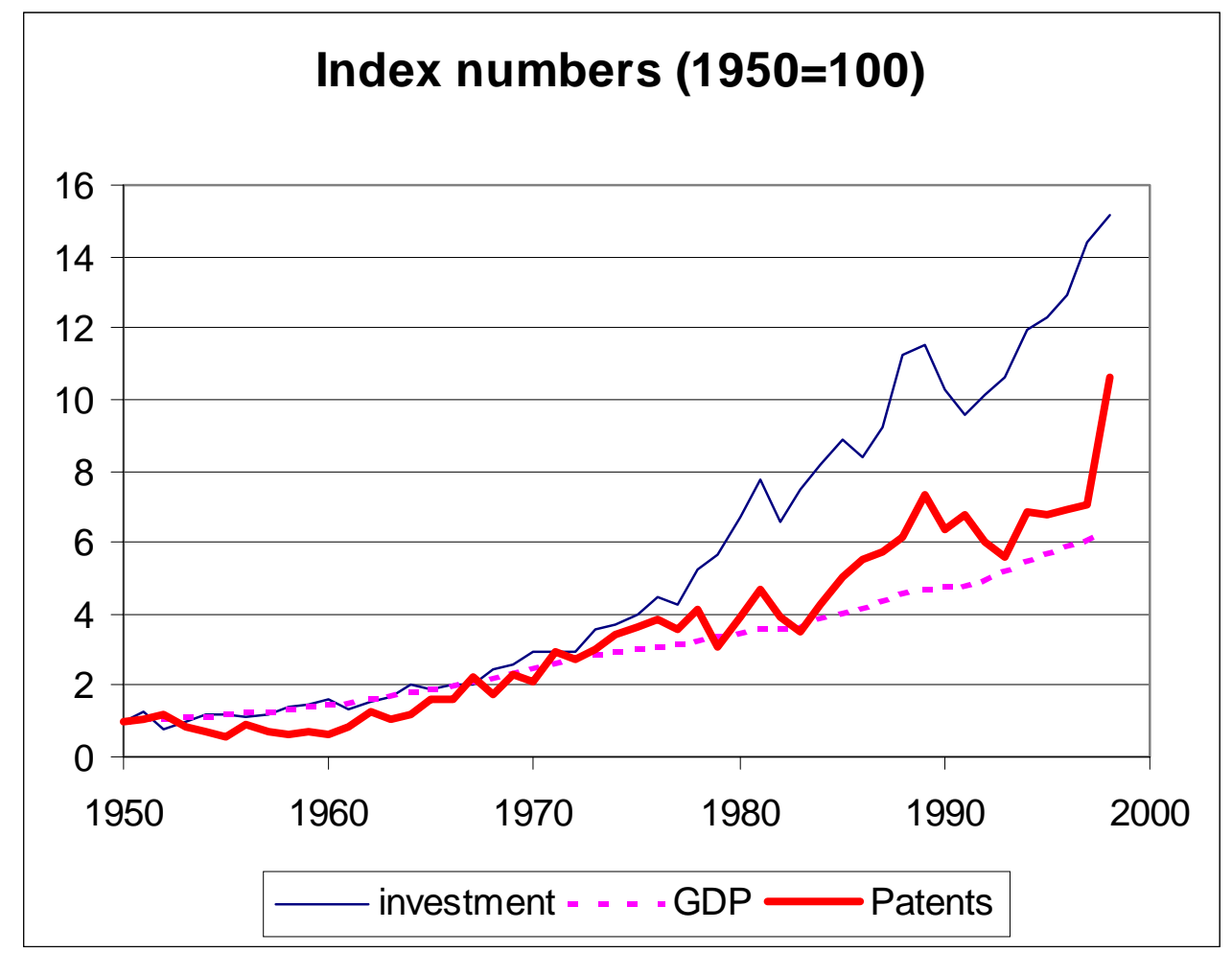

Sources: GDP: Groningen Growth and Development Center, Groningen University, the Netherlands. Investment: Penn World Tables, downloaded from NBER, OECD Economic Outlook, June 1999. Patents: US Patent and Trademark Office.

GDP in Figure 3 has a growth trend with no observable cyclical pattern, this is despite the fact that GDP has experienced clear business cycles throughout the period. The scale of the index and the strong trend disguise the relatively lower amplitude volatility in GDP compared to investment and patent indices. Classical cycles with deviations from the trend, and growth cycles of percentage changes in growth rate are the two common methods of clearly identifying the peaks and troughs in GDP volatility. Pagan (1996, pp. 5-8) provides a history and dating of the Australian business cycles in both forms. ${ }^{19}$

\footnotetext{
${ }^{19}$ Mercer-Melbourne Institute (various issues) provides a quarterly bulletin on "Reading of the Business Cycle". This up-dates the Pagan (1996) history to the current situation.
} 
Equation 4 is the basis of the following empirical investigation. A panel data set is established with annual ABS data for I, $\Pi$ and RD for the period 1984-85 to 1997-98. This covers the complete available annual RD data published by ABS. Two-digit industry classifications are used to match respective spending in I (gross fixed capital expenditure) and RD (business R\&D expenditure) over the same year and then related to same year's $\Pi$ (gross profits).

The industry classification up till 1991-92 is ASIC, then its replacement by ANZSIC is used, with a concordance conducted based on the ABS guidelines. Twelve initial ASIC manufacturing sectors have been reduced to eight sectors in this concordance process. The remaining sector is "Other Manufacturing", but due to the major shifting of subgroups within this category between ASIC and ANZSIC, concordance could not be done, and the whole sector has been removed from the panel data set. Four service sectors and the mining sector are the non-manufacturing sectors in the panel data. Communication Services and Scientific Research sectors have not been included since no profit figures are available. This establishes a panel data set of 13 industry sectors with 178 observations. $^{20}$

Unit root tests are applied to this panel data and t-test statistics are obtained for intercept (no trend) and for intercept with linear time trend. Both tests fail to reject the null of a unit root in Investment, RD and $\Pi$. The UR tests are based on the work of Im et al. (1996) under the special circumstances of panel data. This involves doing a Dickey-Fuller test for each industry and averaging the t-test statistics. ${ }^{21}$ This result implies that the OLS equations that are estimated have to be checked for cointegration, something that is done by performing the same Im et al. (1996) test on the residuals from the OLS results.

The complete panel data set is put in log form, as per equation 4 with dummy variables (DV) for the intercept value. Finance \& Insurance and Property \& Business sectors are removed when the log form of the data is taken for regressions, since both exhibit negative profit figures. This leaves a data set of 11 industries and 152 observations. OLS regression is performed on the remaining 11 useable industry sectors with one year lagged $\mathrm{RD}$ and $\Pi$ variables in respect to the I variable. The lags on both $\mathrm{RD}$ and $\Pi$ allow time for the dynamic circular flows from these two variables to impact on the I variable, and guarantee exogeneity of the regressors. The lags reduce the observations by one per the eleven industry sectors, i.e. 141 observations remaining. Six separate regressions are performed by choosing different sample sets from the panel data, reflecting various aspects of the theoretical framework discussed in Section 3. Current (not real) dollar values of all data are used to simulate the investment decision-making processes occurring at the time and are not deflated by inflation indices.

Sample 1, as the standard regression result of the complete data, is the point of reference for all the other sample regressions. Sample 2 is the available manufacturing industries only and this set most resembles Sample 1. To examine volatility, the two expansions out of the early 1980s and early 1990s recessions are looked at separately in Samples 3 and 4.

\footnotetext{
${ }^{20}$ See Appendix A for ABS sources of data, industry sector classifications and concordance issues.

${ }^{21}$ See Appendix B for detailed initial UR results.
} 
Finally, the evolutionary life-cycle method reveals growth and mature industries, which are then set up as separate Samples 5 and 6 respectively. As noted below, seven industries are initially identified, unfortunately three growth industries have inadequate data for OLS regressions to be conducted. All three are service-based industries, which indicates the paucity of data coming out of statistical bureaus on the expanding services sectors.

Table 2 provides the essential results from the OLS regressions for each of the sample sets. As already mentioned, we performed Im et al. (1996) root tests on the residuals of the regressions documented in Table 2. In all cases, these tests rejected the hypothesis of a unit root, indicating that the results in the table can indeed be interpreted as cointegration equations. The details of these tests are documented in Table 3.

Table 2: OLS regression results in six sample sets

\begin{tabular}{|c|c|c|c|c|c|c|c|c|c|}
\hline Sample & R sq. & F sigf. & $\begin{array}{c}\text { RD } \\
\text { coef. }\end{array}$ & $\begin{array}{c}\text { P value } \\
\text { (RD) }\end{array}$ & $\begin{array}{c}\Pi \\
\text { coef. }\end{array}$ & $\begin{array}{c}\text { P value } \\
(\Pi)\end{array}$ & $\begin{array}{c}\text { RD } \\
\text { PD coef }\end{array}$ & $\begin{array}{c}\Pi \\
\text { PD coef }\end{array}$ & $\begin{array}{c}\text { DV } \\
\text { PD coef }\end{array}$ \\
\hline 1 & 0.9417 & $6.8 \mathrm{E}-72$ & 0.193 & $3.3 \mathrm{E}-08$ & 0.233 & $4.7 \mathrm{E}-07$ & 0.2128 & 0.1869 & 0.8527 \\
\hline 2 & 0.8857 & $1.5 \mathrm{E}-39$ & 0.140 & 0.00067 & 0.250 & $2.6 \mathrm{E}-06$ & 0.1163 & 0.2103 & 0.7920 \\
\hline 3 & 0.9642 & $6.4 \mathrm{E}-17$ & 0.534 & $2.8 \mathrm{E}-05$ & 0.147 & 0.21532 & 0.4598 & 0.0524 & 0.8992 \\
\hline 4 & 0.9568 & $5.3 \mathrm{E}-38$ & 0.217 & 0.00253 & 0.208 & $7.7 \mathrm{E}-05$ & 0.1337 & 0.2183 & 0.9064 \\
\hline 5 & 0.9343 & $3.9 \mathrm{E}-25$ & 0.142 & 0.00296 & 0.158 & 0.00481 & 0.1764 & 0.1602 & 0.8786 \\
\hline 6 & 0.9605 & $8.5 \mathrm{E}-52$ & 0.220 & $1.3 \mathrm{E}-06$ & 0.475 & $1.9 \mathrm{E}-09$ & 0.2550 & 0.3651 & 0.8673 \\
\hline
\end{tabular}

Table 3: Sample UR tests

\begin{tabular}{|c|c|c|c|c|c|}
\hline Sample & Description & $\begin{array}{c}\text { Years in } \\
\text { sample }\end{array}$ & $\begin{array}{c}\text { Sample } \\
\text { Observa- } \\
\text { Tions }\end{array}$ & $\begin{array}{c}\text { UR average } \\
\text { t statistic }\end{array}$ & $\begin{array}{c}\text { Critical } \\
\text { value at x\% } \\
\text { significance }\end{array}$ \\
\hline 1 & $\begin{array}{c}\text { All 11 } \\
\text { industries }\end{array}$ & $\begin{array}{c}1984-85 \text { to } \\
1997-98(14 \\
\text { years })\end{array}$ & 141 & -2.74 & $\begin{array}{c}-2.66 \\
(5 \%)\end{array}$ \\
\hline 2 & $\begin{array}{c}\text { Manufact'ng } \\
\text { industries }\end{array}$ & all 14 years & 104 & -2.6 & -2.54 \\
$(10 \%)$
\end{tabular}


Explanation of the results is left for the next section when a story is fashioned around these results. Sufficient here to define the terms in Table 2 and the strength of the regression results. The $\mathrm{R}$ squares in all six samples show strong correlations in the relation to the equation 4 with $\mathrm{RD}$ and $\Pi$ both lagged one year behind the I variable. All six samples also indicate very significant F-values. The next column shows the elasticity coefficient for RD. Generally this coefficient is roughly the same, if not higher, than the $\Pi$ elasticity coefficient in a column further on. Only in Sample 6 (mature industries) is this general pattern broken, with $\Pi$ coefficient more than double the value of the RD coefficient. This seems intuitively appropriate, as mature industries would tend to be influenced by profits much more than RD in their investment decisions. The respective $\mathrm{RD}$ and $\Pi$ coefficients have P-values as shown in the relevant columns, reflecting strong significance in the coefficient figures. The one non-significant exception is $\Pi$ for Sample 3 (Expansion A).

Unreported in Table 2 are the DV coefficients for each industry in each of the sample regressions. All DV coefficients for all six sample sets range closely around four to six, indicating a tightness of fit of all DV variables, irrespective of the tests conducted. Sample 3 (Expansion A) has many more DV coefficients around 3.1 to 3.8 than in any other sample set. Sample 5 (growth industries) has all its coefficients around the higher range of 4.9 to 6.3 , whereas Sample 6 (mature industries) in contrast has all its coefficients around the lower range of 2.6 to 4.1 which indicates stronger profit-based investment decision-making going on in mature industries.

The final three columns are partial determination (PD) coefficients for three independent variables RD, $\Pi$, and DV (as "one" variable) for each of the sample sets. These are obtained by conducting partial $\mathrm{R}$ square regressions for each of the three variables in the $\log$ series while holding the other two variables constant. ${ }^{22}$ Such regressions give some perspective on the proportions of the $\mathrm{R}$ square that can be attributed to each of the independent variables. Each of the figures in these three columns can be viewed as an index number explaining a proportion of variation in the I dependent variable. This can be useful in understanding the variance (or volatility) when one sample is compared to another in terms of the circular flow process. Not surprising in the model based on equation 4 , in which the other important variables of change in profits, excess capacity and gearing ratios are explicitly absent, that DV has much the highest PD coefficient variable in each of the six sample sets. Relevant to the dynamic innovation and investment analysis is the relative values of $\mathrm{RD}$ and $\Pi$ within each sample and how these relative values alter across these samples. Exposition of these relative values occurs in the following section as part of the complete analysis of the results.

\footnotetext{
${ }^{22}$ The formula used for partial determination coefficient for I on RD (holding $\Pi$ and DV constant): The numerator is: (sum of squares of regression [SSR] of all variables) minus (SSR of all variables except RD). The denominator is: (total SSR model with all variables [TSS]) minus (SSR of all variables including RD) plus (numerator). For example in Sample 1 for RD: TSS is 112.6797, SSR (all variables) is 106.1153, SSR (all variables except RD) is 104.3399. Plugging the values in the formula, the coefficient is calculated to be 0.21288 as an index number for RD as the PD coefficient. Similarly, partial coefficients can be found for I on $\Pi$, and I on DV for each sample set.
} 
The evolutionary method is based on the industry life-cycle relations between innovation and investment as depicted in Table 1. The case study pattern-matching approach to qualitative data is applied in this method (see Yin, 1994). Specifically, this requires the adoption of the available14 ABS industry sectors as individual case studies, upon which the grid matrix of Table 1 is applied. ${ }^{23}$ All the available annual data on R\&D for each industry are laid out on a spreadsheet with respect to human resources devoted to $R \& D$; $R \& D$ expenditure as a proportion of total $R \& D$ expenditure for the respective year; type of $\mathrm{R} \& \mathrm{D}$ expenditure and activity. The level and rate of capital expenditure are also laid for the corresponding years. For this method there is no need for a complete data set on an annual basis, all available data are included in the spreadsheet. In most industries, sporadic R\&D data are available back to 1976-77 and all of it is included. Each case study industry has its own pattern with respect to the above data, this pattern is identified and classified in terms of per cent proportions; high/moderate/low levels; rising/falling/stable over time. Then each industry is matched with the other industries to identify similar patterns in specific aspects. These patterns are compared to the templates of Table 1 and Figure 2 so that the industries can be classified in their stage of industry development. This process provided the classification of growth and mature industries used in Samples 5 and 6 in the panel data sets.

Table 4 summarises the results from evolutionary method. Not only have these results been used to identify Samples 5 and 6, but they can also be used in their own right as qualitative empirics in the analysis of results. Table 4 is arranged with all the identified seven "growth" industries first, followed by the seven "mature" industries. Each of the two sub-groups is arranged from highest to lowest R\&D intensity. There are specific grid matrices for each of the static, dynamic and volatility classifications; and individual spreadsheets for each industry. Any of these separate tables can be obtained on request from the corresponding author. A key to the code classifications appears at the bottom of Table 4.

Brief outline of Table 4 results are presented here before they are incorporated in the analysis in the next section. Second and third columns are quantitative R\&D indicators of the pace of innovation across industries in snapshot and early 1990s growth rates, providing a reference point. These indicators are too limited and specific for evaluation of the evolution processes going on over a longer time that influence innovation and investment. A broader picture emerges over the next few columns. Size (static column), change (dynamic column) and variance (volatility column) relate R\&D to investment expenditure. In these respects the seven "growth" industries show quite different patterns of growth in both R\&D and investment. Four "growth" industries (three of them services) exhibited strong investment growth in the 1980s, but were relatively weak in 1990s. The other three showed the reverse. There seems to be large investment volatility across this "growth" group as a whole, but with generally rising R\&D input. The seven "mature" industries are more consistent across Table 4 with weak and relatively stable capital

\footnotetext{
${ }^{23}$ All 11 industries in the panel data set are included, plus the three service sector industries that were dropped from the panel data due to the lack of a statistically complete set (Communication services) or due to negative profits in $\log$ form (Property \& Business; Finance \& Insurance).
} 
Table 4: Evolutionary life-cycle results

\begin{tabular}{|c|c|c|c|c|c|c|c|}
\hline Industry & $\begin{array}{c}\text { R\&D } \\
\text { intensity }\end{array}$ & $\begin{array}{c}\text { R\&D } \\
\text { growth }\end{array}$ & $\begin{array}{c}\text { Static } \\
\text { R\&D-I }\end{array}$ & $\begin{array}{c}\text { Dynamic } \\
\text { R\&D-I }\end{array}$ & $\begin{array}{c}\text { Volatility } \\
\text { R\&D-I }\end{array}$ & $\begin{array}{l}\text { Recovery } \\
\text { f. troughs }\end{array}$ & $\begin{array}{l}\text { Panel } \\
\text { data cl. }\end{array}$ \\
\hline $\begin{array}{l}\text { Machine } \\
\& \text { equip. }\end{array}$ & 6.4 & $13 \%$ & High-low & stab-decl & $\begin{array}{c}\text { nodf-grea } \\
\text { L - } \Downarrow\end{array}$ & $\begin{array}{l}\text { Strong- } \\
\text { moderate }\end{array}$ & Growth \\
\hline $\begin{array}{c}\text { Wood \& } \\
\text { paper. }\end{array}$ & 5.0 & $85 \%$ & Low-low & grth-grth & $\underset{\Uparrow}{\text { grea-grea }}$ & $\begin{array}{l}\text { Strong- } \\
\text { v. strong }\end{array}$ & Growth \\
\hline $\begin{array}{l}\text { Property } \\
\text { \& bus. }\end{array}$ & 1.4 & $14 \%$ & High-mod & grth-stab & $\begin{array}{c}\text { grea-grea } \\
\Uparrow\end{array}$ & $\begin{array}{l}\text { Moderate- } \\
\text { moderate }\end{array}$ & Growth \\
\hline $\begin{array}{c}\text { Finance } \\
\text { \& ins. }\end{array}$ & 0.3 & $-11 \%$ & Low-low & decl-decl & $\begin{array}{c}\text { grea-grea } \\
\Downarrow\end{array}$ & $\begin{array}{l}\text { Moderate } \\
\text { - v. weak }\end{array}$ & Growth \\
\hline $\begin{array}{c}\text { Wholesale } \\
\& \text { retail }\end{array}$ & 0.3 & $4 \%$ & High-high & grth-decl & $\begin{array}{c}\text { grea-less } \\
\Uparrow \Downarrow-\Downarrow\end{array}$ & $\begin{array}{l}\text { Moderate } \\
\text { - v. weak }\end{array}$ & Growth \\
\hline $\begin{array}{l}\text { Print, pub } \\
\& \text { record. }\end{array}$ & 0.3 & $-13 \%$ & Low-low & grth-grth & $\underset{\Uparrow}{\text { grea-grea }}$ & $\begin{array}{l}\text { Weak - } \\
\text { strong }\end{array}$ & Growth \\
\hline $\begin{array}{l}\text { Commu- } \\
\text { nications }\end{array}$ & n.a. & n.a. & Low-low & decl-decl & $\begin{array}{c}\text { grea-less } \\
\Downarrow\end{array}$ & $\begin{array}{l}\text { V.strong- } \\
\text { v. strong }\end{array}$ & Growth \\
\hline $\begin{array}{c}\text { Petrol, } \\
\text { coal\&chm }\end{array}$ & 4.6 & $11 \%$ & High-low & decl-decl & $\begin{array}{c}\text { grea-grea } \\
\Downarrow\end{array}$ & $\begin{array}{c}\text { Strong - } \\
\text { none }\end{array}$ & Mature \\
\hline Metals & 2.9 & $12 \%$ & High-low & decl-stab & $\begin{array}{c}\text { nodf-great } \\
\text { H }-\Downarrow\end{array}$ & $\begin{array}{c}\text { None- } \\
\text { moderate }\end{array}$ & Mature \\
\hline $\begin{array}{l}\text { Non- } \\
\text { metals }\end{array}$ & 2.6 & $31 \%$ & Low-low & decl-stab & $\begin{array}{c}\text { nodf-less } \\
\mathrm{H}-\Downarrow\end{array}$ & $\begin{array}{c}\text { Weak - } \\
\text { moderate }\end{array}$ & Mature \\
\hline Mining & 2.6 & $46 \%$ & High-high & grth-stab & $\begin{array}{c}\text { grea-less } \\
\Uparrow-\Downarrow\end{array}$ & $\begin{array}{c}\text { Weak - } \\
\text { weak }\end{array}$ & Mature \\
\hline $\begin{array}{l}\text { Food, bev } \\
\text { \& tob. }\end{array}$ & 1.9 & $24 \%$ & High-low & decl-decl & $\begin{array}{c}\text { grea-less } \\
\Downarrow\end{array}$ & $\begin{array}{l}\text { Weak- } \\
\text { weak }\end{array}$ & Mature \\
\hline $\begin{array}{l}\text { Tex, clot, } \\
\text { foot \& lt. }\end{array}$ & 0.7 & $19 \%$ & Low-low & stab-decl & $\begin{array}{c}\text { nodf-grea } \\
\text { L - } \Downarrow\end{array}$ & $\begin{array}{c}\text { Moderate } \\
\text { - weak }\end{array}$ & Mature \\
\hline $\begin{array}{l}\text { Transport } \\
\text { \& storage }\end{array}$ & n.a. & n.a. & $\begin{array}{l}\text { Low- } \\
\text { mod }\end{array}$ & stab-stab & $\begin{array}{c}\text { nodf-nodf } \\
\text { L }\end{array}$ & $\begin{array}{c}\text { Moderate- } \\
\text { moderate }\end{array}$ & Mature \\
\hline KEY & $\begin{array}{c}\text { R\&D exp. } \\
\text { /total ind. } \\
\text { revenue } \\
(1995 / 96) \\
24\end{array}$ & $\begin{array}{l}\text { Av.annual } \\
\text { real rate } \\
\text { from } \\
1990 / 91 \\
\text { to } \\
1995 / 96^{25}\end{array}$ & $\begin{array}{l}\text { Av. relat. } \\
\text { size by } \\
\text { exp. and } \\
\text { human } \\
\text { resource }^{26} \text { effort. }^{26}\end{array}$ & $\begin{array}{c}\text { Growth, } \\
\text { stable or } \\
\text { decline of } \\
\text { exp.late } \\
\text { 1970s- } \\
\text { 1990s. }{ }^{27}\end{array}$ & $\begin{array}{c}\text { Greater, } \\
\text { less, no } \\
\text { diff. vol: } \\
\Uparrow \Downarrow \text { dir. } \\
\text { L/H nodf- } \\
\text { low/high }\end{array}$ & $\begin{array}{c}\text { Strong, } \\
\text { mod.or } \\
\text { weak } \\
\text { early1980 } \\
\& 1990 \text { s } \\
\text { troughs. }^{29}\end{array}$ & $\begin{array}{l}\text { Classif. of } \\
\text { industry } \\
\text { in relation } \\
\text { to both } \\
\text { R\&D and } \\
\text { I across } \\
\text { rows. }\end{array}$ \\
\hline
\end{tabular}

\footnotetext{
${ }^{24}$ Source: Mercer-Melbourne Institute (1998, Issue 2, p. 45, Table 2.2).

${ }^{25}$ Source: Mercer-Melbourne Institute (1998, Issue 2, p. 45, Table 2.2).

${ }^{26}$ See Appendix C for details of industry classifications (high-moderate-low) and their size calculations with respect to expenditure relative to proportions spent on R\&D and I by the private business sector as a whole. First classification applies to R\&D, second to I (R\&D - I). R\&D size also incorporates proportion of human resources devoted.

${ }^{27}$ See Appendix C for industry classifications and their relative change from the late 1970s to the late 1990s expenditure in respect to R\&D and I. First classification applies to R\&D, second to I (R\&D - I).

${ }^{28}$ See Appendix C for description of volatility in R\&D and I from the late 1970s through to the late 1990s. Arrows indicate general trend in the direction of volatility over this period. $\mathrm{H}$ means high relative volatility in expenditure, while L means low relative volatility. The code "nodf" means no difference in volatility over the period.
} 
expenditures, but with a large component of $R \& D$ still important in the six manufacturing industries.

Finally, a simple and strongly prevailing pattern of R\&D type can be discerned across all 14 industry sectors. In the 1970s and early 1980s, labour costs were the predominant type of expenditure in all sectors, this has shifted to "other current costs" in all but three (Property \& bus; Finance \& ins.; Printing, publ. \& record.). This reflects the outsourcing by contract of much of the R\&D effort, while labour remains predominant. R\&D activity is consistently "experimental" by around 60-70\% in all sectors (Wood \& paper moved up to $91 \%$ in the late 1990s), that reflects prototype development for Australian conditions of overseas technology. Communications (based on limited data) is the only sector where "applied research" is around 45-50\% of all research activity. Human resources effort (in person years) devoted to $\mathrm{R} \& \mathrm{D}$ is relatively low for all sectors except notably high for Machinery \& equipment, and some increase in the two growth service sectors, Wholesale $\&$ retail and Property \& business.

\section{The Story - Analysis of results}

Rather than judging a set of hypotheses based on the empirical results presented in Section 4 above, this section aims to tell a plausible dynamic story that has empirical patterns which match many aspects of theory outlined in Section 3. First pattern is derived from the OLS regressions, then the second pattern comes from the evolutionary life-cycle results.

Initially, the OLS 11 industries "standard" in Table 2 indicates that lagged R\&D influence on investment (0.19) for all industries across the whole statistical test period is only slightly less than profits lagged $(0.23)$ and the difference is statistically nonsignificant. This sets the foundation for innovation as a linked flow variable to investment, along with profits. Partial determination coefficients show that variation in investment accounted by $\mathrm{RD}_{\mathrm{t}-1}$ (at index number 0.21 ) slightly exceeds $\Pi_{\mathrm{t}-1}(0.19)$. To see the relative influence of RD on I, the other sub-sample results from Table 2 provide an indication in relation to the standard result:

- Manufacturing sees RD influence fall significantly relative to $\Pi(0.13$ c.f. 0.25$)$, and variation index also fall relative to $\Pi(0.12$ c.f. 0.21$)$. Profits as the dependent variable strengthens in manufacturing alone compared to standard. The role of RD seems to be significant in the influence and variation on investment to the nonmanufacturing: mining (old paradigm) and services (new paradigm).

- Expansion A shows a massive rise in the influence of RD (0.53), and the variation index also similarly improves ( 0.46 for RD c.f. 0.05 for $\Pi$ ). Variable $\Pi$ is nonsignificant in this regression. The expansion out of the 1980s trough has RD of significant importance both in terms of influence and on the steep rise in this

\footnotetext{
${ }^{29}$ See spreadsheets of individual industries showing relative expansions of capital expenditure after respective troughs in economic activity. Strong, moderate and weak indicate relative strength of capital expenditure expansions. "V" refers to "very". Spreadsheets available from corresponding author.
} 
expansion. The rise of the new paradigm is in evidence in this expansion, with wholesale \& retail, property \& business, machinery \& equipment all showing strong $\mathrm{RD}$ and I expansion (finance \& insurance and communications also show this pattern in Expansion A on the individual spreadsheets but are not in the panel data).

- Expansion $B$ has results that fall back close to the standard results in influence of RD $(0.22)$ and $\Pi(0.21)$, but with the partial coefficients showing the variation index close to the manufacturing only results $(0.13$ c.f. 0.22$)$. Here DV is relatively the strongest variation index (0.91). Two effects are taking place. First is the relatively slow rise out of the early 1990s trough compared to Expansion A, due to greater debt restructuring requirements and high excess capacities (traditional Kaleckian factors). Second is the relatively low RD base in industries that produced strong I expansions (wood \& paper; print, pub \&record; transport \& storage). Property \& business and communications are strong I contributors in Expansion B, with rising RD influence but are not in the panel data set (see individual spreadsheets).

- Growth industries has the most peculiar results. Both RD and $\Pi$ fall to 0.14 and 0.16 (respectively) with non-significant difference between the two, and the DV coefficients at their largest. Statistically there are many complex issues going on here that remain unexplained. The partial coefficients are also low for both RD and $\Pi$ (0.18 and 0.16 , resp.). The "statistical loss" of three crucial services industries matters (see Expansion A and B discussions where these industries are important from the case study spreadsheet evidence). Wood \& paper has the strongest industry I expansion out of the early 1990s trough with significantly strong growth in RD (see Table 4). In the "growth sample regression" the DV coefficient for this industry (4.99) is significantly lower than wholesale \& retail DV coefficient (6.32) that has considerably less RD influence. Thus, the regressions are getting the directions of influence consistent with the evolutionary method.

- Mature industries has a more consistent pattern. Both RD and $\Pi$ have stronger coefficients, but $\Pi$ is significantly more influential at 0.47 (c.f. 0.22 for $\mathrm{RD}$, close to standard), which is supportive of the Kaleckian role of profits in mature industries. DV coefficients are at their lowest influence here relative to all other samples Variation through partial coefficients shows again the role of $\Pi$ relative to $\mathrm{RD}(0.37$ c.f. 0.255 , resp.). This regression sample strongly supports the role of profits that "fossilises" reinvestment in mature industries, despite the ascent of the new technology paradigm.

A look at the partial coefficient indices as a whole is instructive. All six samples have DV indices around a tight band ( 0.79 for manuf. to 0.91 for Expansion B), $\Pi$ indices have a wider range ( 0.05 for Exp. A to 0.36 for mature), but generally around 0.21 . The RD indices are the widest ( 0.13 for Exp. B to 0.46 for Exp. A), reflecting the much more differential effect on investment variation from this variable compared to $\Pi$ and DV. This is consistent with the role of innovation, particularly in a period of strong structural change, and reflects RD variation in itself contributing to the volatility of the I variable. 
An examination of the evolutionary method results from Table 4, confirming the patterns of innovation, profits and investment identified through the OLS regression results and adding a degree of qualitative pattern behaviour not available from regressions. Table 4 breaks up into two sections reflecting differences between the seven growth and seven mature industries. An analysis of each follows:

- Growth industries group: There is a marked diversity in this group ("growth through diversity"). The two strong manufacturing industries, machinery \& equipment and wood \& paper, begin their growth from very different basis. The former was a large RD-based sector in the 1970s, which has been able to transform itself effectively by adopting reasonably quickly the new information technology paradigm. The latter was a small sector in severe decline in the 1970s, which has had a very strong turnaround in the 1990s from a very low base. All the four "growth" service industries are also different, with finance \& insurance the most problematic in this group, having had a very impressive 1980s expansion but a very poor record in both R\&D and I in the 1990s. Printing, publishing \& recorded media sector is showing nascent signs of growth, especially in the area of multi-media activities only recently added into this sector. Communications and property \& business providing a strong base of investment through innovation, but through different mechanisms. Property \& business has seen significant rise from spending only $5.6 \%$ of total R\&D expenditure for the year 1976-77, to where the latest figures show spending of 15.3\% in 1997-98. Communications R\&D is poorly reported in the ABS, but available data shows it as the only sector with nearly $50 \%$ in applied research. Also, studies in this industry indicate that innovation comes through large enterprises that have much different innovation mechanisms than standard R\&D spending (Rogers, 1998).

- Mature industries group: There is a marked uniformity in this group, based around the protection of existing MOP and the tendency for capital stock to become "fossilised" in Salter's terms. The larger "mature" industries remain strong through substantial reinvestment programmes. Thus, despite weak investment cycle expansions they have large absolute investment spending (especially transport \& storage and mining industries). This indicates that the old energy-based paradigm still represents a power base to capitalism and will remain so for quite a while yet. The interesting point is that as a group there is a large labour cost-experimental R\&D input into this foundation, with relatively stable but trend declining investment cycles. Only one is a service industry, and it is the most stable of all 14 industries but with virtually no R\&D (transport \& storage). The manufacturing "mature" industries depend on R\&D for reinvestment and their relative monopoly control in the economy, however their R\&D tends to be "experimental", which is endogenous innovation. Even their adoption of the information technology paradigm tends to be an "add-on" to their MOP rather than fundamental change to the nature of their production systems.

In terms of Figure 2, the Australian two-digit private business industry sectors can be placed within the following stages of industrial development: 
- Infant: Scientific research.

- Growth - Part I (rapidly evolving): *Property \& business; Communications; Machinery \& equipment.

- Growth - Part II (consolidating): *Wholesale \& retail; Finance \& insurance.

- Mature: *Mining; *Transport \& storage; Petrol, coal \& chemical; Metals; Nonmetals; Food, beverage \& tobacco; Textile, clothing, footwear \& leather.

- Transition: Wood \& paper; Printing, publishing \& recorded media.

The four significant large capital expenditure industries in Australia are marked with an asterisk (*). This spreads the private gross fixed investment over the major stages of industrial development reflecting both the old and new paradigms in action despite the clear shift in growth and transition to information technology systems.

The above analysis of results can be placed within the theoretical structure of Section 3 in a way that relates the evolution of industrial development to the circular flow of innovation and investment. Many studies confirm Australia's comparative disadvantage in R\&D intensive manufacturing and that Australia has benefited less from international R\&D spillovers than all or most other small OECD nations (Engelbrecht, 1998, p. 184). Our results on R\&D type activity echo this concern, with dominance of labourexperimental research and relatively low human resources effort. In his own study Engelbrecht (1998) notes that the role of business R\&D has increased from the beginning of the 1980 s to $0.87 \%$ of GDP in 1995 , still well below the OECD at $1.45 \%$. This places the RD variable into context, although Gregory (1993) argues that Australian innovation peculiarities are better captured in the L term of equation 1 under the complete NIS.

Tensions exist between the mature industry sectors with "fossilised" MOP and relatively weak RD and the growth industry sectors with information technology systems backed by rising business RD. The tensions materialise in two forms. First is as "roadblocks" by the still strong monopoly controlled mature industries to further innovation and investment. This creates, as noted in the theory, by a mismatch of current investment to new available technology and the weakening of the "cluster-bunching" effect in the growth sectors. Second is with endogenous innovation supporting mature industries provides weak input into a mechanism for strong investment cycle recovery. This exhibited itself with the extended period taken for investment to recover out of the early 1990s trough compared to the early1980s. Then once a strong investment boom is under way (as in the late 1990s), these tensions create susceptibility to downturns. This is reflected in the "safety" option of profit-based reinvestment in mature industries, or in speculative behaviour in shares on "Internet" stocks rather than productive investment in new technology. Supporting this proposition in Australia is the "extremely volatile" business investment through 1998-99, which has produced a net zero growth over this period (MercerMelbourne Institute, 1999, Issue 3, pp.24-5). The two innovation-based tension mechanisms exacerbate volatility in investment. In Australia's case this means a lengthy time for investment to establish a sustainable recovery and, then, strong GDP growth with growing susceptibility to a sharp and deep investment downturn. ${ }^{30}$

\footnotetext{
${ }^{30}$ Compared to the European case where volatility means shorter time to renew investment, but with frequent shallow investment downturns and relatively lower GDP growth rates (see Section 3).
} 
The tensions between the two exogenous innovation forces described above also manifest themselves in the two circular flow processes described in Section 3.2. Both processes are in evidence at the same time in Australia. The virtuous circle feeds through both RD and $\Pi$ to greater I, and stronger GDP to produce a strong recovery phase and powerful susceptibility pressures towards the peak of the investment cycle. The vicious circle is evident at two levels. At the national level, the tensions described above materialise through relatively poor Australian RD flowing into the NIS. This places increasing pressure on the L term to sustain Australia's endogenous innovation input into investment, which has significant public policy implications. Either dependence must continue to increase on external private sector L inputs like licensing, foreign direct investment, joint ventures from abroad, borrowed technology; or the public sector needs to reverse its current tendency for reducing its innovation input and, instead, expand domestic-based innovation. If external-based $\mathrm{L}$ is not forthcoming (or external private innovation shifts towards other peripheral nations), then I can be under severe threat in its ability to deliver strong sustainable levels. Then $\Pi$-based reproduction in the old technology paradigm dominates, with lower profits and a vicious circle effect becomes powerful.

At the regional level, small isolated peripheral sub-national areas in Australia have been historically based on the old paradigm and as a result are in economic decay. The vicious circle is operating very powerfully in these areas, as reduced $\Pi$ from traditional energy and resources-based production reinforces low investment levels. Precious little $\Pi$ is flowing into $\mathrm{RD}$, and the $\mathrm{L}$ term is only sustained with the old paradigm-based input from external sources. Here, there is a strong case for public policy intervention towards a strategic shift to the new paradigm and an exogenous innovation base that can end this vicious circle, since systemic failures prevent "market forces" from providing this structural change. ${ }^{31}$

\section{The Technical Details and Limitations}

The research and analysis above has some serious limitations stemming from the technical details involved in collating and analysing data, applying such data results to the issue at hand, and in the theoretical tools currently available to derive conclusions. These three sets of limitations are briefly acknowledged in this section in terms of the technical details they contain. In this way, the signs are clear that overcoming such technical problems will also reduce the limitations of this study.

\subsection{Collating and analysing data}

R\&D data has only relatively recently been available in OECD nations, and collation has been particularly late in Australia, when it supposedly became an annual survey only from 1984-85. ${ }^{32}$ This provides only a limited number of observations (152) for empirical

\footnotetext{
${ }^{31}$ For detailed analyses of this regional policy issue in relation to Australia, with specific application to the small peripheral region of Tasmania, see Courvisanos (2000a, 2000b, 2000c).

${ }^{32}$ R\&D data became available in the late 1970s in most OECD nations (Mercer-Melbourne Institute, 1998, Issue 2, p. 39).
} 
analysis, and even less in the sub-samples. Even after that date, due to public sector budget cuts, these surveys have not been conducted in some years. In those years (1985$86,1987-88,1989-90)$ the research relies on the stratified random sample of businesses conducted by the ABS on an aggregate basis and then our own interpolation based on the past year and the year ahead. ${ }^{33}$ Also in two industry sectors (Transport \& storage, Finance \& insurance), collection of R\&D data began in 1986-87 instead of the standard 1984-85.

Further statistical problems include need for concordance after the shift from ASIC to ANZSIC classifications, and due to different survey techniques and different categories used in $\mathrm{R} \& \mathrm{D}$ data collation compared to capital expenditure and profit data collation. The latter two are manufacturing-based, while R\&D data has an OECD agreed innovation standard that does not quite coincide with the former. Also, ABS alters categories within industry sectors to reflect changes in their activities, especially in the services sectors. Much of this involves shifting categories from one sector grouping to another, especially out of "other" into specific sectors (e.g. recorded media). Concordance of all such changes requires some arbitrary borderline decisions and inconsistencies inevitably arise.

Manufacturing accounts for around $57 \%$ of total business R\&D, reflecting the dominance of the old manufacturing-based technology paradigm in the supply of machinery and equipment, despite application of R\&D (and innovation) throughout the whole economy. ABS data collection echoes this manufacturing bias in $R \& D$ data collection and also accounts for the very high R\&D intensity for the Machinery \& equipment sector (6.5). Since much of the R\&D effort in the service sectors is based around the new information technology paradigm, it is not classified by ABS as such. This may explain the very low $R \& D$ intensities for the services sectors, especially the 0.3 intensity for Wholesale \& retail and Finance \& insurance sectors (Mercer-Melbourne Institute, 1998, Issue 2, p. 44). For this reason R\&D intensities are not used as basis for regressions in the statistical analysis.

Finally, there are technical problems in the regression analysis of the data. The unit root test accepted the null hypothesis of a unit root in $\mathrm{RD}$ and $\Pi$ in its absolute values. This prevented any regression of variance tests and panel data regressions on the absolute data. The log form of the data for cointegration tests have no such unit root problem, but as a result two crucial service industries are excluded as they have negative profit figures.

\subsection{Applying the results}

In applying the results, the analysis relies on $R \& D$ input and leaves the $\mathrm{L}$ term as given (in the intercept). With R\&D costs below $50 \%$ of total innovation expenditure, there are concerns raised that "...R\&D data may give a misleading picture of the extent of innovation." (Mercer-Melbourne Institute, 1998, Issue 2, p. 45) Based on the circular flow diagram, the linkage of R\&D directly to investment and GDP is stronger than the use of other innovative intellectual property activities of trademarks and patents. ${ }^{34}$ The

\footnotetext{
${ }^{33}$ For details of formula see Appendix A.

${ }^{34}$ As Mortimer (1997, p. 14) states, “[i]nnovation is a key driver of growth, and GDP per capita is highly correlated to R\&D intensity among developed nations".
} 
latter activities often take a longer and certainly more indefinite time period than the oneyear regression lag to become incorporated into the investment process. While the other significant innovative activity of "tooling-up" is directly registered in investment spending itself.

$\mathrm{R} \& \mathrm{D}$ theoretically is also powerful in the way it can link equally with both endogenous and exogenous innovation as shown in the theory discussions earlier. Freeman (1995, p.9) emphasises this point by noting how significant and widespread R\&D activity has developed in the last 50 years, especially in terms of the "monopoly power" of large corporations which play an important part of the circular flow dynamics. Compare this to patent applications which are important for small firms (Rogers, 1998, p.51), but the investment effects are much more tenuous as many small firms fail and the innovation process becomes for complex and convoluted before it registers through the investment process. Further, R\&D is a formal process into business planning and linked directly in many plans to investment decision-making (Engelbrecht, 1998, p.184). This is important for both business and public policy implications that come out of this research.

The recognised weakness in $R \& D$ statistical collection (Section 6.1) and the problems of defining innovation in terms of $R \& D$ as the independent variable (this section), point to the need for a broader innovation research programme. Rooney and Mandeville (1998, p. 461) explain that most NIS studies have been "...rather narrowly focussed on R\&D", when the expanding service sector does not do much R\&D as traditionally defined in Fordist-based ABS data. Service industries innovate via learning-by-doing and adapting information technology to produce new processes and products. This clearly points to the need for broadening the analysis of this paper to incorporate the other forms of innovative activity apart from the R\&D input variable. However, before that can be done at an empirical level, there is need to revise the theory to show clearly how these other innovation activities link to the investment decision-making processes.

\subsection{Theoretical limits}

The R\&D link to investment is only one of the fundamental limitations of the theoretical model used in this research. There is also the neglect of profit changes, excess capacity and increasing risk. These elements figure significantly in the susceptibility investment model of Courvisanos (1996), yet are taken as given here. The data and statistical problems unfortunately compound as attempts are made to introduce these further elements. So this effort can be justified as a "first step".

Of more concern are the limitations of theory construction at this time in the history of economic thought. The continual obsession with the statics (and comparative statics) of innovation and investment limit any efforts to further develop the dynamic analysis of innovation and investment. This is a "mainstream" issue that others can tackle (e.g. adding the concept of innovation into the "options to invest" model of Dixit and Pindyck, 1994). 
From the heterodox perspective, the concern is the lack of coherence in tackling the dynamic issues in this paper. There are the important dynamic analyses of evolutionary and Austrian economics. Both provide long-term perspective, but fail to understand the macroenvironment within which the tensions of the circular flow develop. On the other hand, the Post-Keynesian literature has only sporadically tried to look at these questions through strong behavioural elements in the investment decision-making process, but they generally fail to grasp the dynamic elements that the previous two schools emphasise. The new cognitive approach based on Herbert Simon (and more recently Gerald Silverberg) may provide an important future link between the "givens" of the long-term evolutionary analysis and the behavioural-cum-power relations in the Kaleckian analysis.

\section{The Summary - Policy implications and future research}

The dynamics of innovation and investment involve a threading together evolutionary life-cycle of industry development through innovative processes with Kaleckian extended reproduction through volatility of the investment process. Tension between virtuous and vicious circular flow effects operate to create uncertainty and strategic planning that lead to patterns of industry and economy-wide development of cumulative expansion (and booms) along with periods of cumulative destruction and insecurity. The latter produce problematic efforts to innovate, which can result in renewed strong investment expansion or extended periods of small investment (mini-)cycles. The results of the panel data regressions support the circular flow mechanisms, while the evolutionary data method supports the stages of industry development and their respective contributions to the circular flow dynamics. The limitations outlined in the previous section point to how this threading together can be effectively tackled further.

From a policy perspective, the analysis in this paper indicates a need for a clear policy framework in a dynamic environment. The policy framework needs to address both the strategic planning of business and the public policies of the state in providing a more stable and sustainable investment regime both in terms of equity and the ecosystem. This requires another research project. Sufficient in this final passage to indicate signs towards the type of policy responses that this research points towards.

In private business, strategic planning must move away from simplistic static flow-charts of "how-to-do", and instead develop a better understanding of the dynamic tensions in the type of circular flow chart presented in this paper. The introduction of major innovations initially depends on finance for $R \& D$ and the ability to develop a cluster of successful innovations that are capable of creating cumulative accumulation. Small firms often lack sufficient retained earnings through profits or a strong equity base. Large firms often are locked-in to sustaining old capital stock values to the detriment of innovative activity and maintaining a vicious circle of low innovation and investment. Transition of large firms with the synergistic support of small innovate firms provides some route out of these tensions towards a virtuous circle effect. Even such expansion needs to be carefully monitored to avoid the cumulative susceptibility of over-investment and very sharp investment downturn that replaces virtuous with vicious circle effects. 
For public policy, the issue is whether the current circular flow effects are sustainable and in what direction. If regions, sectors or even nations exhibit strong remorseless vicious circles based on support for "fossilised" capital values, then systemic failure of capitalism ensures that shifting to an innovative creative accumulation can only be done through strategic intervention. This requires an understanding of human agency processes in the private sector, particularly in relation to uncertainty and ability to gain voluntary conformity for a "new direction" that does not merely tamper at the edges with static policy tools of depreciation allowances and more subsidies. Even booming virtuous circles are problematic given their susceptibility to investment downturns that can destroy voluntary conformity already there. Thus, systemic failure is also waiting on the wings of boom economies and industries that need state amelioration (or what Adolph Lowe called "regularisation") of the investment cycle. This is required to ensure long-term stability and importantly continued voluntary conformity in periods when virtuous circles tend to mature into fossilised monopoly power positions that are destabilising. 


\section{References}

Arestis, P., Driver, C. and Rooney, J. (1985-86) "The Real Segment of a UK post Keynesian Model", Journal of Post Keynesian Economics, Volume 8 (2), winter, pp. 163-81.

Asimakopulos, A. (1975) “A Kaleckian Theory of Income Distribution”, Canadian Journal of Economics, Volume 8 (3), pp. 313-33.

Asimakopulos, A. (1977) "Profits and Investment: A Kaleckian Approach", in harcourt, G.C. (ed.) The Microeconomic Foundations of Macroeconomics, Bouldor, Col.: Westview Press, pp. 328-42.

Asimakopulos, A. (1983) “A Kaleckian Profits Equation and the United States Economy, 1950-82”, Metroeconomica, Volume 35.

Baran, P. and Sweezy, P. (1966) Monopoly Capital, New York: Monthly Review Press.

Boatwright, J.W. (1954) "Comment" on De Chazeau paper, in National Bureau of Economic Research, Regularization of Business Investment, Princeton: Princeton University Press, pp. 109-12.

Collins, A. and Yao, S. (1998) "On Innovative Activity Over the Business Cycle: A Note", Applied Economics Letters, Volume 5, pp. 785-8.

Courvisanos, J. (1996) Investment Cycles in Capitalist Economies: A Kaleckian Behavioural Contribution, Cheltenham: Edward Elgar.

Courvisanos, J. (2000a) "Regional Economic Decay and Regeneration Under Structural Change", in Falk, I. (ed.) The Dead Centre: Regional Australia in Crisis, Melbourne: NCVER, Chapter 4.

Courvisanos, J. (2000b) "Region in Transition: Schumpeterian Road to Recovery in Tasmania", Journal of Economic and Social Policy, Volume 4

Courvisanos, J. (2000c) "IT Investment Strategy for Development: An 'Instrumental Analysis' Based on the Tasmanian and New Brunswick Information Technology Strategies", Prometheus, March.

Del Monte, G. (1981) "Review of MOSYL, 1967 to 1981", Review of Economic Conditions in Italy, Volume 2, June, pp. 323-8.

Dixit, A. and Pindyck, R. (1994) Investment Under Uncertainty, Princeton: Princeton University Press. 
Dodgson, M. and Rothwell, R. (eds.) (1994) The Handbook of Industrial Innovation, Cheltenham: Edward Elgar.

Driver, C. and Moreton, D. (1992) Investment, Expectations and Uncertainty, Oxford: Basil Blackwell.

Dunn, S.P. (2000) "Galbraith, Uncertainty and the Modern Corporation", in Keaney, M. (ed.) Economist with a Public Purpose: Essays in Honour of John Kenneth Galbraith, London: Routledge.

Engelbrecht, H-J. (1998) "Business Sector R\&D and Australia's Manufacturing Trade Structure", Applied Economics, Volume 30, pp. 177-87.

Freeman, C. (1994) "Innovation and Growth", in Dodgson and Rothwell (eds.) (1994), pp. 78-93.

Freeman, C. (1995) “The 'National System of Innovation' in Historical Perspective", Cambridge Journal of Economics, Volume 19, pp. 5-24.

Freeman, C. and Perez, C. (1988), "Structural Crises of Adjustment, Business Cycles and Investment Behaviour", in Dosi, G., Freeman, C., Nelson, R., Silverberg, G. and Soete, L. (eds.) Technical Change and Economic Theory, London: Pinter, pp 38-66.

Freeman, C. and Soete, L. (1997) The Economics of Industrial Innovation, Third edition, London: Pinter.

Galbraith, J.K. (1974) The New Industrial State, Second revised edition, Harmondsworth: Penguin (original 1967 publication).

Geroski, P.A. and Walters, C.F. (1995) "Innovative Activity Over the Business Cycle", Economic Journal, Volume 105, July, pp. 916-28.

Gomulka, S. (1990) The Theory of Technological Change and Economic Growth, London: Routledge.

Gomulka, S., Ostaszewski, A. and Davies, R.O. (1990) "The Innovation Rate and Kalecki's Theory of Trend, Unemployment and the Business Cycle", Economica, Volume 57, November, pp. 525-40.

Gregory, R.G. (1993) “The Australian Innovation System”, in Nelson R.R. (ed.) National Innovation Systems: A Comparative Analysis, New York: Oxford University Press, pp. 324-52.

Hollanders, H., Soete, L. and ter Weel, B. (1999) "Trends in Growth Convergence and Divergence and Changes in Technological Access and Capabilities", MERIT Research Memorandum 99-019, Maastricht: Maastricht University. 
Hossain, F. and Chung, P.J. (1999) "Long-run Implications of Neoclassical Growth Models: Empirical Evidence from Australia, New Zealand, South Korea and Taiwan", Applied Economics, Volume 31 (9), September, pp. 1073-82.

Im, K.S., Pesaran, M.H. and Shin, Y. (1996) "Testing for Unit Roots in Heterogeneous Panels", Working Paper, Cambridge, U.K.: University of Cambridge.

Jankowski, J.E. (1998) “R\&D: Foundation for Innovation”, Research Technology Management, Volume 41 (2), pp. 14-20.

Kaldor, N. (1961) "Capital Accumulation and Economic Growth", in Lutz, F.A. and Hague, D.C. (eds.) The Theory of Capital, New York: St Martin’s Press, pp. 177228.

Kaldor, N. (1966) Causes of the Slow Rate of Economic Growth in the United Kingdom, Cambridge: Cambridge University Press (reprinted in Further Essays on Economic Theory, London: Duckworth, pp. 100-38).

Kalecki, M. (1937) “The Principle of Increasing Risk”, Economica (New Series), Volume 4 (16), November, pp. 440-6.

Kalecki, M. (1954) Theory of Economic Dynamics, London: George Allen \& Unwin.

Kalecki, M. (1962) "Observations on the Theory of Growth", Economic Journal, Volume 72, pp. 134-53.

Kalecki, M. (1971) Selected Essays on the Dynamics of the Capitalist Economy 1933-1970, Cambridge: Cambridge University Press.

Kalecki, M. (1991) "The Problem of Effective Demand with Tugan-Baranovsky and Rosa Luxemburg", in Osiatyński, J (ed.) Collected Works of Michat Kalecki, Volume II: Capitalism - Economic Dynamics, Clarendon Press, Oxford, pp. 451-58 (original 1967 Polish publication in Ekonomista, Volume 2, pp. 241-9).

Kleinknecht, A. (1987) Innovation Patterns in Crisis and Prosperity: Schumpeter's Long Cycle Reconsidered, London: Macmillan.

Lavoie, M. (1992) Foundations of Post-Keynesian Economic Analysis, Aldershot: Edward Elgar.

Malerba, F. and Orsenigo, L. (1993) "Technological Regimes and Firm Behaviour" Industrial Corporate Change, Volume 2, pp. 45-71.

Mensch, G. (1979) Stalemate in Technology: Innovations overcome Depression, New York: Ballinger (original 1975 German publication Das Technologische Patt: Innovation Uberwinden die Depression, Frankfurt: Umschau). 
Mercer - Melbourne Institute (various issues) Quarterly Bulletin of Economic Trends, Parkville: Melbourne Institute of Applied Economic and Social Research, The University of Melbourne.

Mortimer, D. (Chairman) (1997) Going for Growth: Business Programs for Investment, Innovation and Export, Canberra: Commonwealth of Australia, July.

Nickell, S. and Nicolitsas, D. (1996) "Does Innovation Encourage Investment in Fixed Capital?", The Centre for Economic Performance Discussion Paper No. 309, London: London School of Economics and Political Science, October.

O’Connor, J. (1973) The Fiscal Crisis of the State, New York: St Martin's Press.

Pagan, A. (1996) "The Rise and Fall and Rise...of the Business Cycle", Centre for Economic Policy Research Discussion Paper No. 349, Canberra: The Australian National University, September.

Ricottilli, M. (1996) "Technical Progress and the Process of Economic Development: A Keynesian Macroeconomic Problem in an Evolutionary Context", paper presented at The Fourth International Post Keynesian Workshop, University of Tennessee, Knoxville, USA, 27 June- 3 July.

Rogers, M. (1998) "Special Topic: Innovation in Large Australian Enterprises", in Mercer - Melbourne Institute, Quarterly Bulletin of Economic Trends, Issue No. 2, pp. 5060.

Rooney, D. and Mandeville, T. (1998) "The Knowing Nation: A Framework for Public Policy in a Post-industrial Knowledge Economy", Prometheus, Volume 16 (4), pp. 453-67.

Salter, W.E.G. (1960) Productivity and Technical Change, Cambridge: Cambridge University Press.

Sawyer, M. (1996) "Kalecki on Trade Cycle and Economic Growth", in King, J.E. (ed.), An Alternative Macroeconomic Theory: The Kaleckian Model and PostKeynesian Economics, Boston, Kluwer Academic, pp. 93- 114.

Scherer, F.M. (1984) Innovation and Growth: Schumpeterian Perspectives, Cambridge, Mass.: The MIT Press.

Schmookler, J. (1966) Invention and Economic Growth, Cambridge, Mass.: Harvard University Press.

Schumpeter, J.A. (1939) Business Cycles; A Theoretical, Historical and Statistical Analysis of the Capitalist Process, 2 Volumes, New York: McGraw-Hill. 
Steindl, J. (1976) Maturity and Stagnation in American Capitalism, Second edition, New York: Monthly Review Press.

Steindl, J. (1979) "Stagnation Theory and Stagnation Policy", Cambridge Journal of Economics, Volume 3 (1), March, pp. 1-14.

Steindl, J. (1991) "Comment attached to letter for the editor - dated 20 January 1978", in Osiatyński, J (ed.) Collected Works of Michat Kalecki, Volume II: Capitalism Economic Dynamics, Clarendon Press, Oxford, p. 596.

Stoneman, P. (1983) The Economic Analysis of Technological Change, Oxford: Oxford University Press.

Sylos Labini, P. (1967) "Prices, Distribution and Investment in Italy, 1951-1966: An Interpretation", Banca Nazionale del Lavoro Quarterly Review, Volume 83, December, pp. 3-57.

Toivanen, O., Stoneman, P and Diederen, P. (1999) "Uncertainty, Macroeconomic Volatility and Investment in New Technology", in Driver, C. and Temple, P. (eds.) Investment, Growth and Employment: Perspectives for Policy, London and New York: Routledge.

Vercelli, A. (1989) "Uncertainty, Technological Flexibility and Long-term Fluctuations", in Di Matteo, M., Goodwin, R.M. and Vercelli, A. (eds.) Technological and Social Factors in Long Term Fluctuations, Berlin: Springer-Verlag, pp. 130-44.

Woolgar, S. (1998) “A New Theory of Innovation”, Prometheus, Volume 16 (4), pp. 44152.

Yin, R.K. (1994) Case Study Research: Design and Methods, Second revised edition, Thousand Oaks, Calf.: Sage. 


\section{Appendix A: Data Sources and Industry Sector Classifications}

Sources for the Panel Data

For I: Australian Bureau of Statistics (various issues), Private New Capital Expenditure, Cat. No. 5625.0, Canberra.

For RD: Australian Bureau of Statistics (various issues), Research and Experimental Development: Business Enterprises, Australia, Cat. No. 8104.0, Canberra.

For П: Australian Bureau of Statistics (various issues), Company Profits, Cat. No. 5651.0, Canberra.

The following 13 industry sectors were set up in the panel data:

$\begin{array}{ll}\text { Industry sector } & \text { ANZSIC classifications } \\ \text { Mining } & 11-15\end{array}$

Manufacturing -

Food, beverages and tobacco (FBT) 21

Textiles, clothing, footwear \& leather (FBTL) 22

Wood \& paper products 23

Printing, publishing \& recorded media 24

Petroleum, coal, chemical \& associated products $\quad 25$

Non-metallic mineral products 26

Metal products $\quad 27$

Machinery \& equipment 28

Services -

Wholesale \& retail trade $\quad$ F-G

Finance \& insurance K

Property \& business services $\quad$ 77, 782-786

Transport \& storage I

Classification changes and resulting data requirements:

1. The ASIC classification has been replaced by the ANZSIC classification (above) from 1992-93. Concordance guidelines set up by ABS to match the two systems of classification are used in developing a consistent panel data series for the 13 sectors as specified above. Some minor classification problems remain which concordance could not resolve which do not make the data completely consistent between the ASIC and ANZSIC categories. ABS authorities have assured us that these inconsistencies are very minor it terms of the total expenditures for these particular industry sectors identified below:

- Mining under ASIC excludes services to mining, while it includes it under ANZSIC.

- Leather manufacturing subdivision (under "Other manufacturing" in ASIC, but can not be identified as a separate item) has been included with the Textile, clothing and footwear (ASIC classification) only from 1992-93 to form TCFL. 
2. Private New Capital Expenditure figures are in accordance with ANZSIC from 198788. Prior to that the figures are in accordance to ASIC and this is unpublished data that is supplied by the ABS office on request.

3. R\&D Expenditure figures are in accordance with ANZSIC from 1992-93. Prior to that the figures are in accordance to ASIC.

4. Company profit (before income tax) figures are in accordance with ANZSIC from 1985-86. Prior to that the figures are in accordance to ASIC. ANZSIC classification is unpublished data and supplied by the ABS office on request.

5. Two ASIC sub-divisions have been combined to form one ANZSIC industry sector and extended back to the beginning of the panel data series. This has been done in two separate cases:

- Basic metal products (ASIC 29) and Fabricated metal products (ASIC 31) form Metal products sector (ANZSIC 27)

- Transport equipment (ASIC 32) and Other machinery \& equipment (ASIC 33) form Machinery \& equipment (ANZSIC 28).

6. Data for Transport \& storage classification category is unpublished and supplied by ABS on request. Categories 263 (paper and paper products) and 264 (printing and allied services) have unpublished RD and I figures, also supplied by ABS on request.

Data available for all industries from 1984-85 to 1997-98 (14 years), except for:

1. R\&D expenditure for years 1985-86, 1987-88, 1989-90 are not available. Only total estimated $R \& D$ expenditure figures are available for these specific years. These estimates have been derived by ABS using a stratified random sample of businesses. The method used to calculate values for these years for the respective industry sectors is as outlined below, using FBT for 1985-86 as the example:

R\&D expenditure on FBT in 1985-86 =

$\{(\mathrm{R} \& \mathrm{D}$ expenditure on FBT in 1984-85 / Total R\&D expenditure on all industries in 1984-85) + (R\&D expenditure on FBT in 1986-87 / Total

$\mathrm{R} \& \mathrm{D}$ expenditure on all industries in 1986-87) $\} / 2$

This expression is multiplied by Total R\&D stratified sample expenditure in 1985-86. This provides the R\&D expenditure for FBT in 1985-86.

2. Transport \& storage and Finance \& insurance have RD figures available only from 1986-87 (12 years), so the panel data series for these two industries began two years later in both cases. This is gives us 178 initial panel data observations instead of 182 (13 industries by 14 years). 


\section{Appendix B: Initial UR Test Results on Panel Data 1984-85 to 1997-98}

Based on 13 industries with 178 observations in non-lagged and non-log form.

\begin{tabular}{|c|c|c|c|c|c|c|}
\hline \multirow[b]{2}{*}{ Industry } & \multicolumn{3}{|c|}{$\begin{array}{c}\text { Test statistics for intercept } \\
\text { (no trend) }\end{array}$} & \multicolumn{3}{|c|}{$\begin{array}{c}\text { Test statistics for intercept and } \\
\text { linear time trend } \\
\end{array}$} \\
\hline & I & RD & $\Pi$ & I & RD & $\Pi$ \\
\hline Mining & 2.81 & -0.77 & -1.87 & 1.50 & -2.40 & -2.33 \\
\hline FBT & 0.72 & -1.40 & 0.217 & -1.15 & -3.00 & -3.68 \\
\hline TCFL & -2.57 & -0.21 & -2.84 & -2.27 & -2.57 & -2.55 \\
\hline $\begin{array}{l}\text { Wood \& } \\
\text { paper }\end{array}$ & -1.90 & -1.35 & -1.16 & -1.87 & -3.08 & -1.87 \\
\hline $\begin{array}{l}\text { Print, } \\
\text { publish. }\end{array}$ & -2.29 & -0.57 & -0.49 & -3.07 & -2.69 & -1.86 \\
\hline $\begin{array}{l}\text { Petrol, } \\
\text { coal \& ch. }\end{array}$ & -2.14 & -0.85 & -2.02 & -1.12 & -1.87 & -2.16 \\
\hline $\begin{array}{l}\text { Non-metal } \\
\text { Products }\end{array}$ & -2.44 & -0.31 & -1.93 & -3.40 & -1.98 & -1.76 \\
\hline $\begin{array}{c}\text { Metal } \\
\text { Products }\end{array}$ & -3.69 & -0.93 & -2.08 & -3.83 & -2.49 & -2.22 \\
\hline $\begin{array}{l}\text { Machinery } \\
\text { \& equip. }\end{array}$ & -0.80 & -0.42 & -1.59 & -1.29 & -2.28 & -2.81 \\
\hline $\begin{array}{l}\text { Wholesale } \\
\text { \& retail }\end{array}$ & -1.47 & -1.13 & -2.31 & -2.33 & -3.41 & -2.23 \\
\hline $\begin{array}{l}\text { Finance \& } \\
\text { insur. }\end{array}$ & -3.68 & -2.79 & -0.82 & -3.65 & -2.12 & -3.82 \\
\hline $\begin{array}{l}\text { Property } \\
\& \text { bus. }\end{array}$ & -2.17 & 2.17 & -2.13 & -2.07 & 0.14 & -1.94 \\
\hline $\begin{array}{l}\text { Transport } \\
\text { \& stor. }\end{array}$ & -2.01 & -2.84 & -1.67 & -1.87 & -2.25 & -2.07 \\
\hline $\begin{array}{l}\text { Av. t-test } \\
\text { statistic }\end{array}$ & -1.67 & -0.88 & -1.59 & -2.03 & -2.31 & -2.41 \\
\hline $\begin{array}{c}\text { Critical } \\
\text { value } \\
(1 \%) \\
\end{array}$ & -2.24 & -2.24 & -2.24 & -2.88 & -2.88 & -2.88 \\
\hline $\begin{array}{c}\text { Critical } \\
\text { value } \\
(5 \%) \\
\end{array}$ & -2.02 & -2.02 & -2.02 & -2.66 & -2.66 & -2.66 \\
\hline $\begin{array}{c}\text { Critical } \\
\text { value } \\
(\mathbf{1 0 \%}) \\
\end{array}$ & -1.90 & -1.90 & -1.90 & -2.54 & -2.54 & -2.54 \\
\hline
\end{tabular}




\section{Appendix C:}

Sources for the Evolutionary Method

$R \& D$ data on human resources, expenditure, type of $R \& D$, type of $R \& D$ activity are all obtained from: Australian Bureau of Statistics (various issues), Research and Experimental Development: Business Enterprises, Australia, Cat. No. 8104.0, Canberra.

Capital expenditure data: Australian Bureau of Statistics (various issues), Private New Capital Expenditure, Cat. No. 5625.0, Canberra.

The data for this method covers the period 1976-77 to 1997-98. The early R\&D data is sporadic, with figures generally for only years 1976-77, 1978-79 and 1981-82. The complete R\&D data series begins from 1984-85 as per the details in Appendix A.

There are 14 industry sectors that form the basis for this evolutionary method. This consists of the same 13 industry sectors as in Appendix A plus Communication Services (ASIC: H; ANZSIC: J). The available data for the Communications sector is too sporadic to be used in the panel data series where continuous annual data is required. The evolutionary method can identify some trends by examining the sporadic data and comparing the trends over time to other sectors with more continuous data series.

\section{Calculations of Code Classifications in Table 4}

1. Human resources devoted to $R \& D$ (persons years):

In analysing the person year effort on R\&D for any industry, a scale has been formulated. The scale is from zero to the highest person years for that particular year for any industry sector. Each year is examined across all industries with the following code classification. The industry with the highest person years is the standard. "High" is where an industry is either 50 per cent or more of the highest person years in the highest industry. If an industry falls within the lower 50 per cent value of the highest person years industry, then "Low" is where it is in the scale of zero to 40 per cent within this sub-category, and "Moderate" is the remaining 60 per cent.

2. $R \& D$ industry expenditure as a proportion of total $R \& D$ expenditure of all industries for that year:

(i) Static measure based on a scale from zero to the highest expenditure for that particular year. For each year comparison is made on the expenditure across all industries.

High: represents the levels of expenditure in the upper one third of the scale.

Low: represents the levels of expenditure in the lower one third of the scale.

Moderate: the remaining third of the values.

(ii) Dynamic measure based on the changes in the percentages of total $\mathrm{R} \& \mathrm{D}$ expended over the period 1976-77 to 1997-98. 
Stable: where the percentages remain roughly the same between the late 1970s and the late 1990s (within two per cent up/down).

Growth: where the percentages show significant increase between the late 1970s and the late 1990s (two per cent or more).

Decline: where the percentages show significant decrease between the late 1970s and the late 1990s (two per cent or more).

3. Investment industry expenditure levels in respect to total gross fixed private capital expenditures for that year:

(i) Static measure based on a scale from zero to the highest expenditure for that particular year. For each year comparison is made on the expenditure across all industries.

High: represents the levels of expenditure in the upper one third of the scale.

Low: represents the levels of expenditure in the lower one third of the scale.

Moderate: the remaining third of the values.

(ii) Dynamic measure based on the rate of expenditure growth for a particular industry from the preceding year.

Stable: where the percentages remain roughly the same between the late 1970s and the late 1990s (average of less than ten per cent change over two years).

Growth: where the percentages show significant increase between the late 1970s and the late 1990s (average of ten per cent or more over two years).

Decline: where the percentages show significant decrease between the late 1970s and the late 1990s (average of ten per cent or more over two years)

4. Volatility of R\&D expenditure from the late 1970s to the late 1990s:

No difference: refers to essentially no change in the proportions of expenditure in industry compared to total R\&D expenditure throughout this period.

High: indicates strong intensity in expenditure proportion changes, reflecting significantly high variance over time (two per cent or more change in proportions). This variance may tend to show upwards $(\Uparrow)$ or downwards $(\downarrow)$ volatility.

Low: indicates weak intensity in expenditure proportion changes, reflecting low variance in percentages over time (less than two per cent). This variance may tend to show upwards $(\Uparrow)$ or downwards $(\Downarrow)$ volatility.

5. Volatility of investment expenditure from the late 1970s to the late 1990s:

No difference: refers to essentially no change in the percentages of expenditure throughout this period.

High: indicates strong intensity in expenditure changes, reflecting significantly high variance in rate of growth over time ( 20 per cent or over). This variance may tend to show upwards ( $\Uparrow$ ) or downwards $(\Downarrow)$ volatility.

Low: indicates weak intensity in expenditure changes, reflecting low variance in rate of growth over time (less than 20 per cent). This variance may tend to show upwards ( $)$ or downwards $(\Downarrow)$ volatility. 
7. Recovery from the two recessions 1981-83 and 1989-91:

Strong: immediately following these years the rate of growth of investment expenditure in the sector shows strong upward movement (in the range of over 20 per cent).

Moderate: immediately following these years the rate of growth of investment expenditure in the sector shows some upward movement, but it is between the range of 10 to 20 percent and may also be delayed by a year or two compared to the "strong" group.

Weak: low (below 10 per cent) growth out of the recession.

None: no growth out of the recession (or even decline in growth rate) after the recession. 